\title{
Geologic Map of Detrital, Hualapai, and Sacramento Valleys and Surrounding Areas, Northwest Arizona
}

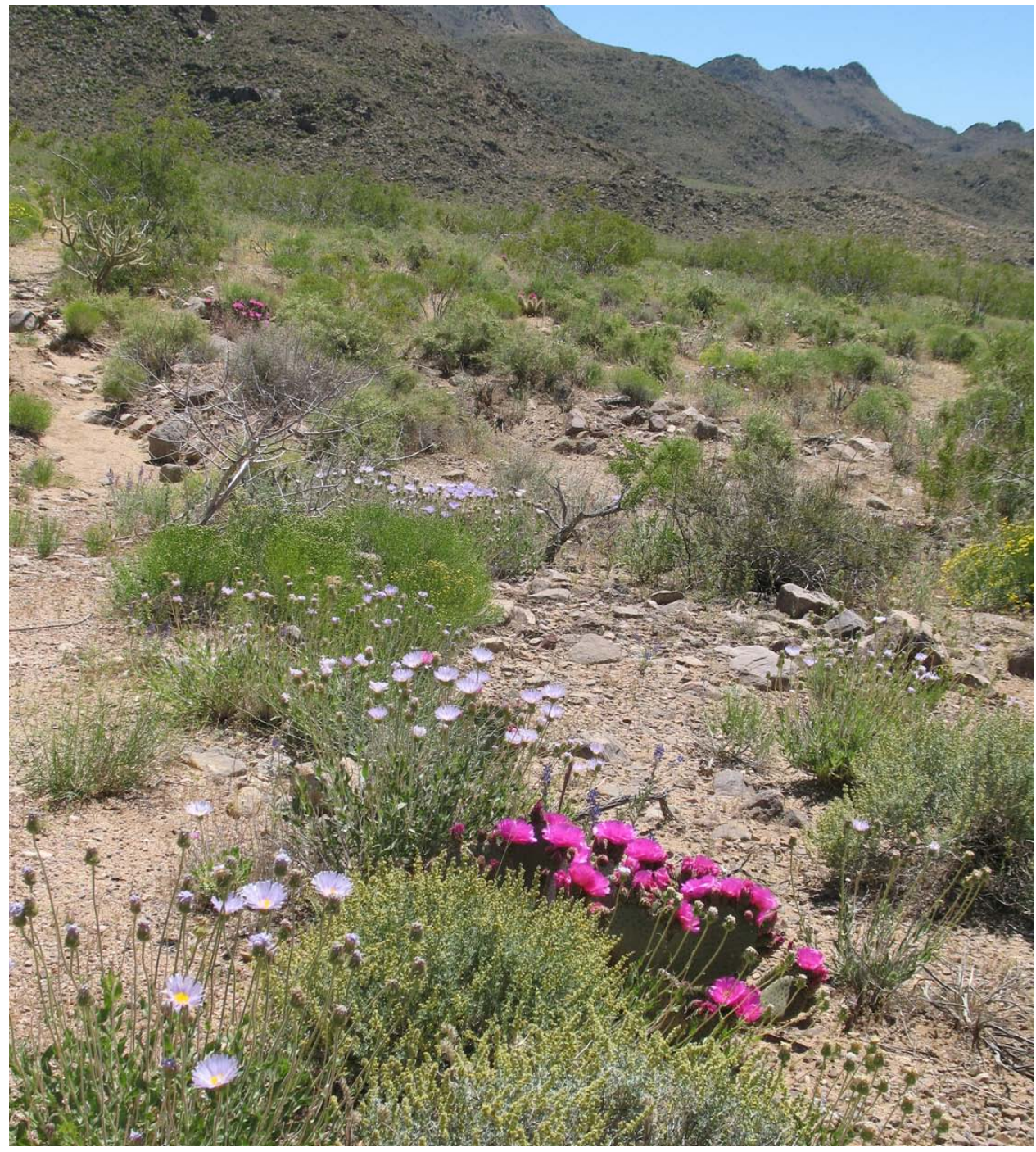

Pamphlet to accompany

Open-File Report 2011-1225

U.S. Department of the Interior

U.S. Geological Survey 
This page intentionally left blank 


\section{Geologic Map of Detrital, Hualapai, and Sacramento Valleys and Surrounding Areas, Northwest Arizona}

By L. Sue Beard, Jeffrey Kennedy, Margot Truini, and Tracey Felger

Pamphlet to accompany

Open-File Report 2011-1225

U.S. Department of the Interior

U.S. Geological Survey 


\section{U.S. Department of the Interior \\ KEN SALAZAR, Secretary}

U.S. Geological Survey
Marcia K. McNutt, Director

U.S. Geological Survey, Reston, Virginia 2011

For product and ordering information:

World Wide Web: http://www.usgs.gov/pubprod

Telephone: 1-888-ASK-USGS

For more information on the USGS-the Federal source for science about the Earth,

its natural and living resources, natural hazards, and the environment:

World Wide Web: http://www.usgs.gov

Telephone: 1-888-ASK-USGS

\section{Suggested citation:}

Beard, L. Sue, Kennedy, Jeffrey, Truini, Margot, and Felger, Tracey, 2011, Geologic map of Detrital, Hualapai, and Sacramento Valleys and surrounding areas, northwest Arizona: U.S. Geological Survey Open-File Report 2011-1225, pamphlet 43 p., 1 map sheet, scale 1:250,000, available at http://pubs.usgs.gov/of/2011/1225/

Any use of trade, product, or firm names is for descriptive purposes only and does not imply endorsement by the U.S. Government.

Although this report is in the public domain, permission must be secured from the individual copyright owners to reproduce any copyrighted material contained within this report. 


\section{Contents}

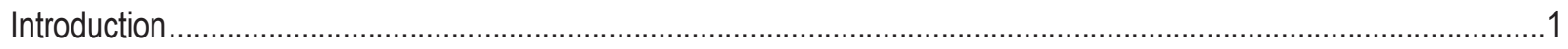

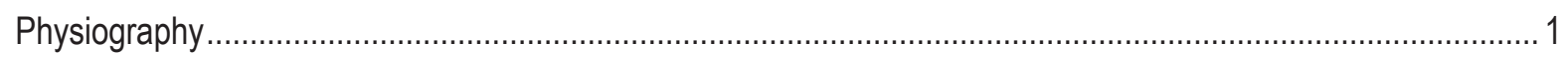

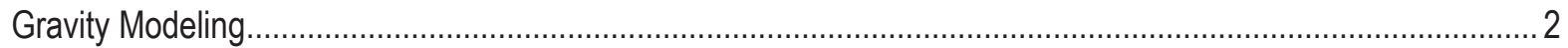

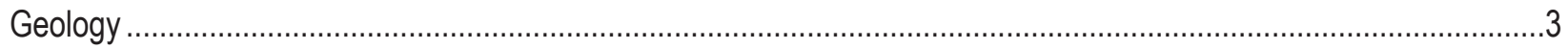

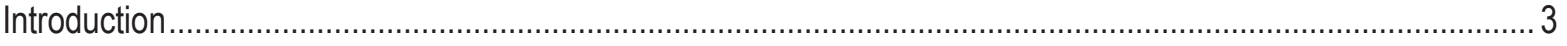

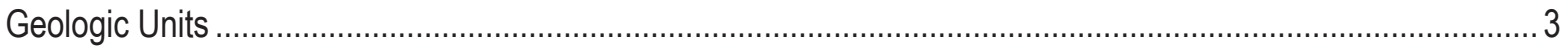

Proterozoic Basement Rocks ............................................................................................................ 4

Paleozoic Sedimentary Rocks............................................................................................... 4

Mesozoic and Cenozoic Intrusive Rocks......................................................................................

Cenozoic Volcanic and Sedimentary Rocks ................................................................................... 5

Pre-extension Sedimentary and Volcanic Rocks.................................................................. 5

Syn-extensional Sedimentary and Volcanic Rocks ..................................................................... 6

Late-stage Interior Basin-fill Deposits.......................................................................................

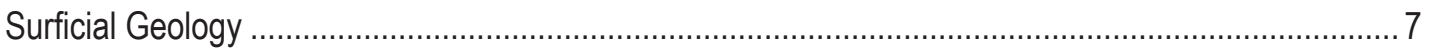

Correlation of Cenozoic Sedimentary Rocks to Alluvial Aquifer Units of Previous Hydrogeologic Studies ....7

Structure



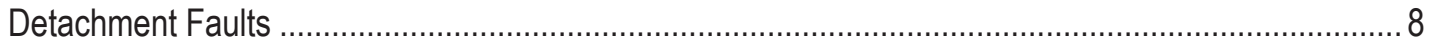

Moderate- to High-angle Normal Faults ........................................................................

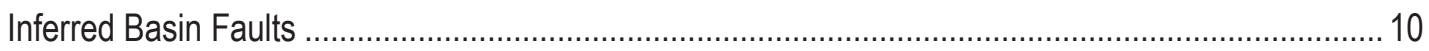

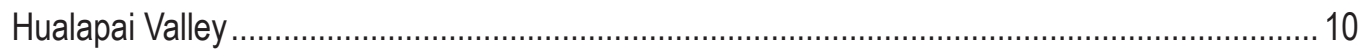

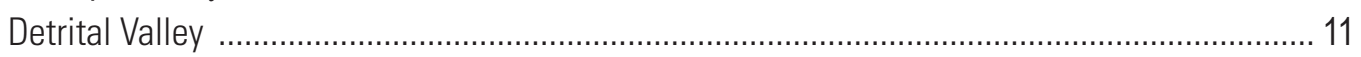

Sacramento Valley ........................................................................................................ 11

Accommodation zone ......................................................................................................... 11

Description of Subbasins Identified from Depth-to-bedrock Gravity Model .................................................. 12

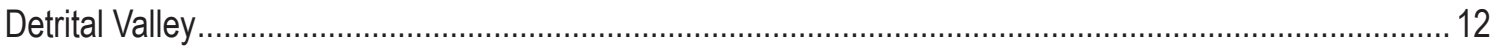

Northern Detrital Subbasin .................................................................................................... 12

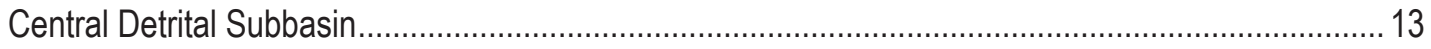





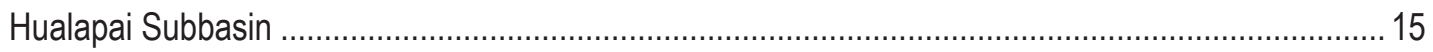

Kingman Subbasin ............................................................................................................ 16

Southern Gregg Subbasin …………………………………………………………….... 16

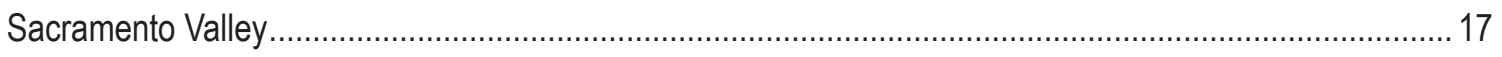

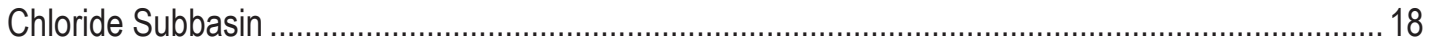

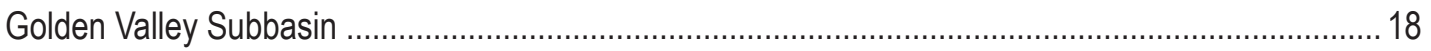

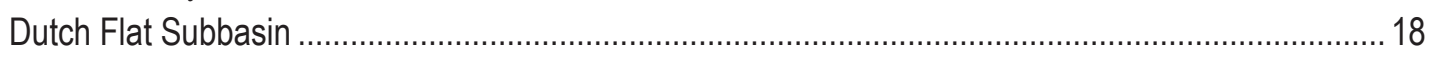

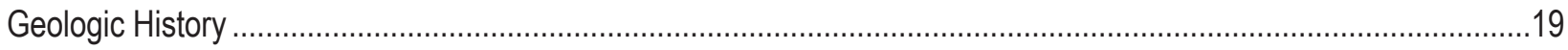

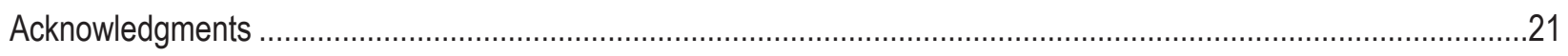

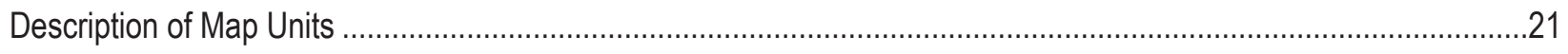

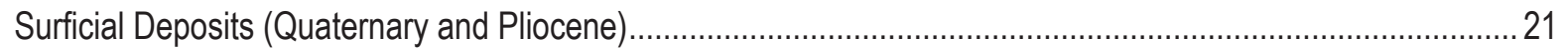

Consolidated Basin-fill Deposits (Pliocene, Miocene, and Oligocene) ......................................................... 23 




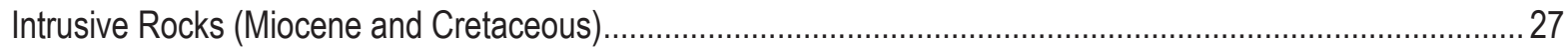

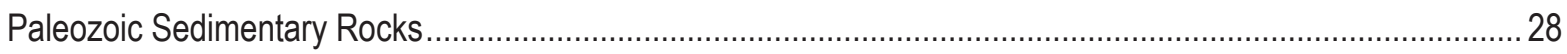

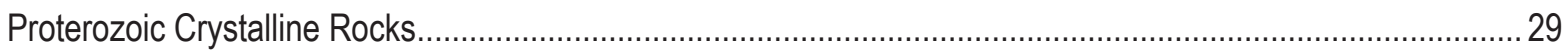

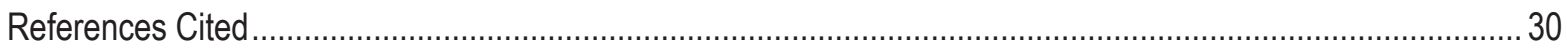

\section{Figures}

1. Shaded-relief map showing hydrologic basin boundary of Detrital, Hualapai, and Sacramento valley basins, and highways, towns, and other physiographic and cultural features referred to in text...

2. Depth-to-bedrock gravity model showing subbasins and estimated thickness of basin fill beneath Hualapai,

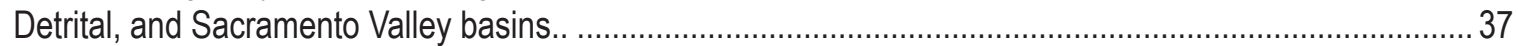

3. Gravity data used to create depth-to-bedrock model, overlain by outline of map area......................................38

4. Regional geologic map showing major geologic features referred to in text. ................................................ 39

5. Schematic sequential cross sections showing extensional basin evolution and stratigraphic relations between older, intermediate, and younger sedimentary rocks. .......................................................... 40

6. Geologic map of study area showing major faults and other structural features............................................... 41

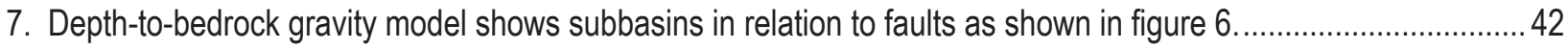

\section{Tables}

1. Geologic characteristics of subbasins for Detrital, Hualapai, and Sacramento Valleys 


\title{
Geologic Map of Detrital, Hualapai, and Sacramento Valleys and Surrounding Areas, Northwest Arizona
}

\author{
By L. Sue Beard, Jeffrey Kennedy, Margot Truini, and Tracey Felger
}

\section{Introduction}

A 1:250,000-scale geologic map and report covering the Detrital, Hualapai, and Sacramento valleys in northwest Arizona (fig. 1) is presented for the purpose of improving understanding of the geology and geohydrology of the basins beneath those valleys. The map was compiled from existing geologic mapping, augmented by digital photogeologic reconnaissance mapping. The most recent geologic map for the area, and the only digital one, is the 1:1,000,000-scale Geologic Map of Arizona (Richard and others, 2000). The larger scale map presented here includes significantly more detailed geology than the Geologic Map of Arizona in terms of accuracy of geologic unit contacts, number of faults, fault type, fault location, and details of Neogene and Quaternary deposits. Many sources were used to compile the geology; the accompanying geodatabase includes a source field in the polygon feature class that lists source references for polygon features. The citations for the source field are included in the reference section.

The map and report were prepared for the Northwest Alluvial Basins project of the Northern Arizona Water Center, U.S. Geological Survey (Anning and others, 2006, 2007). Funding was provided by Arizona Department of Water Resources (ADWR), and the Arizona Water Resources Center and the National Cooperative Geologic Mapping Program, both of the U.S. Geological Survey. A depth-to-bedrock geophysical model used for interpretation of the basin geometry presented here was developed for a forthcoming geohydrologic report for the Northwest Alluvial Basins study; the model is briefly described below and an expanded discussion will be presented in the geohydrologic report. Airborne Transient Electomagnetic survey (GEOTEM) data referred to below and used to interpret some subsurface geologic relations will also be presented in the geohydrologic report.

\section{Physiography}

The Northwest Arizona Alluvial Basins study area (fig. 1) includes Detrital, Hualapai, and Sacramento valley basins, which have similar surface expressions but significant differences in subsurface geology. Hualapai Valley is mostly internally drained (no surface water outlet), fed by Truxton Wash that drains off of the Colorado Plateau from the southeast, and Frees Wash, which has a short reach draining from the Kingman area to the northeast. Hualapai Valley offers no exposures of older basin-fill deposits. In contrast, axial washes in both Sacramento Valley and Detrital Valley drain to the Colorado River; dissection along these washes provides limited exposures of older deposits. Detrital Wash drains northward to Lake Mead, whereas Sacramento Wash drains southward from a divide with Detrital Valley, and then turns westward to drain into the Colorado River at the latitude of Topock, Arizona. Buck Mountains Wash drains the southern part of Sacramento Valley, and joins Sacramento Wash near where it turns westward. The south side of a subtle drainage divide in southern Sacramento Valley drains to the Colorado River by way of washes that join the Bill Williams River (fig. 1).

The eastern edge of the study area is marked by the Grand Wash Cliffs. Hualapai Valley lies just to the west of the Grand Wash Cliffs and is separated from Detrital and Sacramento Valleys to the west by two mountain ranges (fig. 1). The high Hualapai (maximum elevation 8417 
$\mathrm{ft} / 2566 \mathrm{~m}$ ) and somewhat lower Cerbat mountains (7148 ft, $2179 \mathrm{~m}$ ) lie to the south and north of Kingman, respectively. North of Hualapai Valley, a low divide separates the valley from Hualapai Wash to the north, which drains into Lake Mead. Hualapai Wash is bounded to the east by the Lost Basin Range. The northward continuation of the Lost Basin Range is Wheeler Ridge, which extends to the lake. North of the Cerbat Mountains, the White Hills separate Detrital Valley from Hualapai Wash and are separated from the Cerbat Mountains by an northeast-southwest pass at Dolan Springs. The western boundary of Sacramento Valley is formed by the Black Mountains that extend from Hoover Dam at Lake Mead southward to where Sacramento Wash turns westward. Just to the south of this point, the Mohave Mountains extend to the southern end of Sacramento Valley. Buck Mountains form an isolated low range east of the Mohave Mountains, and the McCracken Mountains lie to the southeast and form the southeastern boundary of the valley basin.

The three valleys are underlain by at least eight subbasins that are revealed either on a depth-to-bedrock gravity model (fig. 2) created for the geohydrologic model of the valleys, or definable from well data. Hualapai Valley includes the deep Hualapai subbasin beneath Red Lake, and the Kingman subbasin directly east of Kingman. The southern Gregg subbasin, named by Faulds and others (2010), is located directly north of Red Lake Playa and beneath the upper reaches of Hualapai Wash. Detrital Valley includes the northern, central, and southern Detrital subbasins. In the north, Sacramento Valley is underlain by the Golden Valley and Chloride subbasins. The depth-to-bedrock model also shows a deep subbasin, herein called the Dutch Flat subbasin, in the southern part of Sacramento Valley. Little is known about this sub-basin because it has not been incised and there are no deep wells. The depth-to-bedrock model also indicates a subbasin at the SW end of Sacramento Wash north of Topock; because it is mostly outside of the study area it is not discussed further.

\section{Gravity Modeling}

The depth-to-bedrock model is based on gravity data collected at 1.6-km spacing throughout all three basins (Ivanich and Conway, 2009; Conway and Ivanich, 2008; Mason and others, 2007). Additional historical data were obtained from the Pan-American Center for Earth and Environmental Studies data set (PACES, 2008). Published tide- and drift-corrected gravity readings, station positions, and terrain corrections from 10,681 gravity stations were used in this study, and the complete Bouguer anomaly calculated using standard procedures (fig. $3 \mathrm{~A}$; Hildenbrand and others, 2002). The isostatic compensation effect was modeled using the Airyroot routine (Simpson and others, 1983) and removed from the CBA to create the isostatic anomaly (fig. $3 B$ ). An iterative bedrock-basin anomaly separation process is used to remove the effect of bedrock heterogeneity from the basin-fill anomaly (figs. 3C, 3D; Saltus and Jachens, 1995).

The basin anomaly grid was used to construct a depth-to-bedrock model using the GMSYS-3D software package (Geosoft, Inc., 2010) The basin anomaly reflects the density contrast between higher density bedrock units - generally crystalline and volcanic rocks — and low density sedimentary fill deposits (basin fill). The depth-to-bedrock model consists of 3 layers. The upper two layers represent unsaturated basin fill and saturated basin fill, and are assigned densities of $2.0 \mathrm{~g} / \mathrm{cm}^{3}$ and $2.25 \mathrm{~g} / \mathrm{cm}^{3}$, respectively. The upper layers are separated by a continuous surface defined by the water table, an appropriate simplification because regional aquifers in the area are generally unconfined (Anning, 2007) and the water table coincides with the saturated/unsaturated boundary. The bottom layer of the depth-to-bedrock model represents homogeneous bedrock with a density of $2.67 \mathrm{~g} / \mathrm{cm}^{3}$. The effect of sediment compaction at depth, and the density contrast between deep sedimentary units and bedrock, is difficult to know without deep boreholes. If significant 
compaction was present the density contrast would be lessened, and basin thicknesses would be underestimated. The boundary between the middle layer (saturated basin fill) and the bottom layer (bedrock) is iteratively adjusted during the modeling process so that the calculated gravity response most closely matches the measured gravity data.

No deep wells have been drilled to bedrock within the study area. The deepest well, at 795 $\mathrm{m}$, bottomed in the extensive salt formation in the Hualapai Valley. Therefore, there is no way to validate the depth to bedrock estimates in the deepest basins, and these depths should be taken as estimates only. The depth-to-bedrock model is a good approximation of the bedrock boundaries along the margins and in areas where the bedrock is shallow within the basins. Furthermore, relative depths should also be accurate. However, where there are significant bedrock gravity heterogeneities, such as between the northern Black Mountains and White Hills and between the Buck Mountains and bedrock areas to the north and east (fig. 3C), the depth-to-bedrock model may be less accurate. Specifically, the depth and shape (asymmetry) of the modeled basin anomalies should be used with caution.

\section{Geology}

\section{Introduction}

The Northwest Arizona Alluvial Basins study area lies mostly in the Basin and Range Province (fig. 4), which formed largely by extensional faulting during the Miocene. Bedrock in the area is mainly crystalline Proterozoic rock, either exposed at the surface or overlain by thin to thick sequences of Tertiary volcanic and sedimentary rocks. The bedrock is exposed in fault-bounded ranges, separated by fault-controlled extensional basins that underlie the three alluvial valleys. Paleozoic sedimentary rocks are exposed only along the Grand Wash Cliffs rimming the Colorado Plateau and in Wheeler Ridge, an east-tilted fault block at the far northeastern part of the map area.

The study area straddles the boundary between the Colorado Plateau to the east and the Colorado River extensional corridor part of the Basin and Range to the west (fig. 4). The Colorado River extensional corridor is a 70- to 100-km-wide belt of strong extension (Howard and John, 1987; Faulds and others, 1999) that includes several metamorphic core complexes and trends north along the west side of the study area. Between the Colorado Plateau and Colorado River extensional corridor, extension mostly resulted in mildly tilted to moderately tilted fault blocks and extensional basins.

Extensional basins, which are controlled by large normal faults, were filled with either coarse clastic sedimentary rocks, volcanic rocks, or both (fig. 5A). Many of the older basins (middle Miocene) are not reflected by strong geophysical anomalies because they have been disrupted by subsequent faulting (Langenheim and others, 2010). Instead, most gravity lows correspond to late Miocene and younger basins (subbasins within the valley basins), related to late extension (basin-range), that are still structurally coherent (fig. $5 B$ ). Most subbasins in the study area are no more than 1-3 km deep (fig. 2) and were most likely formed during the late extension. However, the 4.5-km-deep Hualapai subbasin, the deepest and largest in the study area, may be older (Faulds and others, 1997). Late Tertiary and Quaternary surficial deposits drape most of the valley basins, blanketing pediment slopes and the surfaces of the subbasins (fig. $5 \mathrm{C}$ ).

\section{Geologic Units}

Geologic units for the geologic map are summarized briefly below, and described in more detail in the Description of Map Units section. 


\section{Proterozoic Basement Rocks}

Paleoproterozoic metamorphic rocks are the most common basement rock type and include garnet-biotite gneiss, amphibolite, and metasedimentary and metavolcanic rocks (Xgn; see Description of Map Units), intruded by granite and granodiorite (Xg). The metamorphic rocks have been highly deformed by at least two events, imposing strong folding and foliation on the rocks. The earlier event was W- to WSW-directed thrusting, forming a northwest-striking foliation fabric between $1735 \mathrm{Ma}$ and $1720 \mathrm{Ma}$ in the Cerbat Mountains (Duebendorfer and others, 2001). The early fabric was mostly but not completely overprinted by the second event, a northwest-southeast-directed shortening at about $1700 \mathrm{Ma}$ to $1685 \mathrm{Ma}$, which produced tight folds and imparted a strong northeast-striking foliation that is prominent throughout the study area (Duebendorfer and others, 2006; E.M. Duebendorfer, written commun., 2010). Areas in the Peacock, Cerbat, and Hualapai Mountains, where the fabric of the earlier deformation is preserved, exhibit northweststriking foliations. The granite and granodiorite rocks have also been metamorphosed and deformed into biotite and hornblende-bearing quartzofeldspathic gneisses (Xg). Metamorphic grade is mostly granulite facies northwest of a northwest-striking zone that extends from the Hualapai Mountains across the Peacock Mountains to the Grand Wash Cliffs; metamorphic grade is mostly upper amphibolite southeast of the northwest-striking zone (Albin, 1991). These metamorphic rocks range in age from about $1780 \mathrm{Ma}$ to $1650 \mathrm{Ma}$.

The Paleoproterozoic rocks are intruded by Mesoproterozoic granites (Yg) that typically contain large phenocrysts of potassium feldspar that are up to $8 \mathrm{~cm}$ long and comprise 20 to 70 percent of the rock. The feldspars are commonly zoned or reversely zoned (rapakivi texture) and typically aligned in a magmatic foliation. The granitic matrix is quartz, biotite and plagioclase with abundant magnetite or ilmenite. Albin and Karlstrom (1991) report ages of 1.39 Ga and 1.37 Ga for these megacrystic granites in the northern Peacock Mountains.

\section{Paleozoic Sedimentary Rocks}

Cambrian to Devonian sedimentary rocks exposed along the Grand Wash Cliffs dip about 2 to 5 degrees northeast. The basal arkosic Tapeats Sandstone ( $€ b t)$ rests unconformably on Proterozoic rocks and grades upward into the Bright Angel Shale $(€ \mathbf{C b t})$, a burrow-mottled green micaceous shale and reddish-brown sandstone. The Bright Angel Shale (€bt) in turn grades upward into the Muav Limestone $(€ \mathrm{~m})$, a regularly bedded dolomite and limestone unit that forms a distinctive striped cliff. These three Cambrian units form the edge of the Grand Wash Cliffs except where eroded through by early Cenozoic paleo-channels filled with sedimentary and volcanic rocks. The Devonian Temple Butte Formation (Dtb) is mostly stripped back from the cliff edge with only a few remnant ridges preserved within the study area. An early Cenozoic erosion surface prior to faulting is responsible for the stripping and paleovalley development.

The entire Paleozoic section is exposed in east-tilted fault blocks along Wheeler Ridge. There, the massive cliff-forming Mississippian Redwall Limestone (Mr) overlies the Temple Butte Formation and is easily visible because a 30-m-thick cherty interval forms a marker bed on cliff faces. The basal part of the overlying Supai Group (PMs) is a distinctive 20-m-thick slope-forming unit of thin alternating red mudstone and limestone, overlain by medium- to thick-bedded limestone and dolomite, with interbedded crossbedded limestone in the upper part. The uppermost part of the Supai Group is the red to white Esplanade Sandstone, which is about $130 \mathrm{~m}$ thick. This sandstone grades upward into slope-forming red sandstone and siltstone of the Hermit Formation (Ph). The fossiliferous Permian Kaibab and Toroweap Formations (Pkt) form a thick cliff-slope-cliff sequence of limestone, siltstone and mudstone, and limestone at the top of the Paleozoic section. 
The Mississippian to Permian section was truncated southwestward by an early Cenozoic erosion surface prior to faulting. This truncation is visible in Wheeler Ridge by the gradual loss of Permian rock exposures southward, such that the youngest Paleozoic rock exposed at the southern tip of Wheeler Ridge is an eroded thickness of Mississippian Redwall Limestone.

\section{Mesozoic and Cenozoic Intrusive Rocks}

Both Mesozoic and Cenozoic intrusive rocks are exposed in the study area. Late Cretaceous granite, quartz monzonite, and granodiorite (Ki) occur as stocks and small plutons from the Grand Wash Cliffs westward to the Black Mountains. Two-mica, garnet-bearing peraluminous bodies in the Black Mountains, and in the White Hills, most likely intruded at depths of about 10 km (Faulds and others, 2001), whereas plutons in the Cerbat and Hualapai Mountains and Grand Wash Cliffs were intruded at shallow levels, such as a quartz-monzonite body that intruded into the base of the Muav Limestone at Grand Wash Cliffs (Billingsley and others, 2006).

Cenozoic intrusive rocks (Ti) are mostly quartz diorite, quartz monzonite, and granodiorite and include the Mount Perkins pluton $(\sim 16 \mathrm{Ma})$ in the central Black Mountains and the Wilson Ridge pluton $(\sim 13 \mathrm{Ma})$ in the northern Black Mountains. The Mount Perkins pluton was emplaced at about $5 \mathrm{~km}$ depth and subsequently tilted westward during extension, thereby exposing a vertical section of the pluton (Faulds and others, 2001). The Wilson Ridge pluton is tilted northward, thereby exposing deeper levels of the pluton southward. Both plutons are related to associated volcanic sequences exposed nearby (Faulds and others, 2001; Weber and Smith, 1987): the Dixie Queen Mine stratovolcano sequence to the west of the Mount Perkins pluton, and the River Mountain stratovolcano and associated felsic volcanic rocks north and west of Wilson Ridge.

\section{Cenozoic Volcanic and Sedimentary Rocks}

\section{Pre-extension Sedimentary and Volcanic Rocks}

Early Cenozoic erosion beveled Paleozoic rocks, and carved deep northeast-draining paleovalleys that were subsequently filled with pre-extension Paleocene to Early Oligocene sedimentary rocks (Tso). West of the Colorado Plateau margin, Paleozoic strata were completely removed and volcanic rocks were deposited directly on crystalline basement. Relicts of several paleovalleys are found on the western Colorado Plateau, and one forms the divide at Kingman between the Cerbat and Hualapai Mountains. Mafic volcanic eruptions (Tvo), starting about $20 \mathrm{Ma}$ and sourced in the Basin and Range, flowed northeastward along the paleovalleys and now cap remnants of the Paleozoic sedimentary rocks along the Grand Wash Cliffs. The pre-extension volcanic rocks, including andesitic to basaltic flows and vent-facies rocks, and felsic flows, domes and tuffs, are exposed in the southern Black Mountains, around Kingman, in isolated exposures along the flanks of the Cerbat Mountains, and eastward to the Grand Wash Cliffs. Although volcanic rocks occur locally in the northern Black Mountains and White Hills, they are too local and thin to show at the map scale. The deposits are mostly no more than a few hundred meters thick except in the southwestern Black Mountains where they may be as much as a kilometer thick (Pearthree and others, 2009).

The volcanic rocks are regionally overlain by or are intercalated with the $18.5 \mathrm{Ma}$ Peach Spring Tuff (Nielson and others, 1990) and related ash-flow and ash-fall tuffs derived from the Silver Creek Caldera (Tto; fig. 4; Pearthree and others, 2009). These strata form distinctive marker beds and are therefore used to separate the lower sequence of volcanic rocks from younger volcanic and sedimentary rocks. In addition, extensional faulting mostly postdates these strata. 


\section{Syn-extensional Sedimentary and Volcanic Rocks}

Syn-extensional deposits are mostly confined to the western part of the study area, north and west of the Cerbat and Hualapai Mountains. Early syn-extensional volcanic units include rhyolitic to andesitic flows and flow breccias, and rhyolitic to dacitic breccias and domes that are about 15 Ma to $18 \mathrm{Ma}(\mathbf{T v m})$. They are intercalated locally with poorly sorted cobble to boulder conglomerate and large avalanche deposits (Tsmo) in the White Hills and in southwestern Sacramento Valley. Coeval faulting formed half-graben basins as much as 2 to $3 \mathrm{~km}$ deep. The half-graben basin fill is mostly volcanic in the western White Hills and Black Mountains and mostly clastic in the eastern White Hills (Faulds and others, 2010). The rocks are faulted and typically tilted 30 to 90 degrees.

In the central and southern Black Mountains, the volcanic section is capped by olivine basalt flows and breccias that are about $15 \mathrm{Ma}$ to $13 \mathrm{Ma}$ (Tbo), and are faulted but only tilted a few degrees. Distinctive ash-flow tuffs and associated ash-fall tuffs (Tty; including the tuff of Bridge Spring and tuff of Mount Davis about 15.0 - 15.2 Ma) together form a regional stratigraphic marker bed in the central and northern Black Mountains and in the White Hills. Overlying this ash-flow tuff marker unit are rhyolitic flows, breccias, domes and pyroclastic flows (Tvy), exposed only in the White Hills and northern Black Mountains, and in the southernmost tip of Sacramento Valley. Volcanism waned by about $12 \mathrm{Ma}$ to $13 \mathrm{Ma}$, with only local basaltic volcanism continuing, as described below.

Younger intermediate-age sedimentary rocks, deposited during peak extension, include red to tan sandstone and conglomerate with local gypsum, limestone and mudstone, exposed from the Black Mountains eastward to Hualapai Wash (Tsmy). These rocks mostly post-date volcanism and are about $9 \mathrm{Ma}$ to $13 \mathrm{Ma}$. In the White Hills they are mostly conglomerate and sandstone. This unit is inferred to form the bulk of the fill in Hualapai subbasin, where it comprises up to 2-3 km of halite, shale, gypsum/anhydrite and laterally equivalent sandstone and conglomerate at the margins of the subbasin (Faulds and others, 1997). These "peak" extensional basin deposits are tilted and faulted, but less so than the early intermediate-age sedimentary rocks (Tsmo).

Isolated outcrops of $\sim 8$ - to 12-Ma tholeiitic intermediate-age (Tbm) basalt flows overlie the late synextensional deposits in the White Hills and on the west side of Detrital Valley, as well as in far southwestern Sacramento Valley. Basalt flows are locally faulted, and slightly to moderately tilted, but less so than the underlying sedimentary rocks.

\section{Late-stage Interior Basin-fill Deposits}

Late extensional faulting formed narrow elongate subbasins (described in detail below) that are imaged in the depth-to-bedrock model (fig. 2). These basins were internally drained and filled by fine-grained sand, silt and clay, as well as gypsum and halite in some locations (Tsy). Hualapai Limestone was deposited at the north end of Hualapai Valley (Tsh), and lacustrine sediments of the Bouse Formation were deposited at the west end of Sacramento Valley (Tsb). In contrast to the older rocks, these deposits are mostly flat lying, or only locally slightly tilted. Young ( 5-6 Ma) basalt flows (Tby) overlie basin-fill deposits on the west side of Detrital Valley and on the northeast flank of the Mohave Mountains. Isolated deposits of sand and gravel mapped as Tg are exposed against the north and west flank of the Hualapai Mountains; their age and significance are poorly understood. Outcrops of Tg near Lake Mead are gravel and sand, and include both alluvial fan deposits and early Colorado River gravels and sands that represent integration of the Colorado River and signal the end of interior basin deposition. Some of the deposits were previously mapped as Chemehuevi Formation (Laney, 1979), but are now thought to be older (House and others, 2005). 


\section{Surficial Geology}

Surficial geologic units include sediments that form a veneer on the older rocks in the subbasins and (or) mantle the cliff and mountain slopes. These sediments are unconsolidated, and include alluvial fan, plain and pediment deposits (Qa, QTa); talus, landslide and colluvial deposits are included in the units and only large landslide deposits are mapped separately (QTI). The QTa deposits include a thick carbonate soil horizon in northern Detrital Valley. Areally restricted surficial deposits include axial alluvial wash sediments $(\mathbf{Q w})$ and eolian sands $(\mathbf{Q e})$. Active and inactive playa deposits form the floor of Red Lake playa in Hualapai Valley (Qp, Qpo). Older and younger Truxton Wash alluvial fan deposits (Qty, Qto) are graded to the active and inactive playa deposits, respectively. Younger Colorado River deposits near Lake Mead are included in the Qa and QTa units.

\section{Correlation of Cenozoic Sedimentary Rocks to Alluvial Aquifer Units of Previous Hydrogeologic Studies}

Hydrogeologic studies by Gillespie and Bentley (1971) and Anning and others (2006) defined the sediments in the three basins as older, intermediate and younger alluvium, of which the older was considered the principal aquifer. The older alluvium, described by these authors as the "stratigraphically oldest and deepest consolidated sedimentary rocks", corresponds to the bulk of Pliocene or older sedimentary rocks shown on the geologic map and in the subsurface of the subbasins (fig. $5 A$ and $5 B$ ). This includes the younger sedimentary rocks (Bouse Formation-Tsb, Hualapai Limestone-Tsh, and the younger sedimentary rock unit-Tsy) and possibly intermediate (Tsmy, Tsmo) and older sedimentary rock units (Tso) where present in the subbasins. Of these, the Tsy unit is the most widespread subsurface unit, and includes coarse-grained clastic rocks near the mountain ranges that grades laterally toward the basin centers into fine-grained clastic rocks, gypsum and (or) halite, and limestone. These rocks can be locally more than a kilometer thick. Distribution of the intermediate-age sedimentary rocks in the subsurface is poorly known, but because these rocks are intercalated with volcanic rocks where exposed, they are probably not widespread. The older sedimentary rocks are only locally exposed at the base of the volcanic section along the Grand Wash Cliffs where preserved in paleovalleys as described earlier.

Along the range fronts, the intermediate alluvium of Anning and others (2007) and Gillespie and Bentley (1971) was described as partly consolidated to slightly consolidated boulder to pebble conglomerate that grades to gravel, silt and sand into the basins. These deposits correspond to the older surficial units shown on the geologic map and figure $5 C$, including the Pliocene older gravel deposits (Tg) and the Pleistocene to late Pliocene older alluvium (QTa), and are typically only exposed near the ranges. Their subsurface distribution is poorly known.

The younger alluvium of Anning and others (2007) and Gillespie and Bentley (1971) was described as weakly consolidated to unconsolidated piedmont, stream and playa deposits. This corresponds on the geologic map and in figure $5 C$ to the active or recently active Holocene to Late Pleistocene alluvial systems, including alluvial fan, plain, and wash deposits, playa sediments, and eolian deposits (Qa, Qw, Qt, Qto, Qp, Qpo, and Qe).

\section{Structure}

The major Cenozoic structures in the study area are high- and low-angle faults, and the Black Mountain accommodation zone (fig. 7). Some of the faults clearly influence the shape and depth of the subbasins; other faults are older and control the distribution of post-Proterozoic consolidated rocks in both the basins and ranges. 
The study area is cut by northwest- to northeast-striking normal faults, mostly moderate- to high-angle faults but also including three large low-angle, or detachment faults (fig. 6). Nearvertical north-northwest-striking faults that cut Proterozoic rocks in the Cerbat, Hualapai, and Black Mountains may have a component of strike-slip motion but have not been studied in detail (Conway and others, 1997; Mörz, 1996). A series of north-northwest-striking normal faults that cut across the Kingman area from the Hualapai Mountains to the southern Cerbat Mountains are smalldisplacement structures. They are most likely not major hydrologic conduits between the valleys, consistent with the 300-m drop in water level from the Kingman subbasin west to Sacramento Valley that suggests little hydrologic connectivity.

In addition to faults that are exposed and have been mapped or inferred by previous workers, interpretation of the depth-to-bedrock gravity model (fig. 2, fig. 7) suggests the presence of several faults for which there is no known surface expression. These are mapped as geophysically defined faults, based on the depth-to-bedrock gravity model, well data (ADWR; http://www. azwater.gov/AzDWR/GeneralServices/Imaging/default.htm), and interpretations of GEOTEM data (M. Truini, unpub. data, 2010). These faults seem to follow a pattern of overlapping synthetic or antithetic normal faults that control the subbasins.

\section{Detachment Faults}

The map area contains three large-displacement detachment faults (fig. 7). In the White Hills, the Cyclopic Mine Fault is a west-dipping low-angle fault that forms the southern extent of the South Virgin -White Hills detachment fault (SVWHDF; Duebendorfer and others, 2010). The fault places intermediate-age volcanic rocks (Tvm) and sediments (Tvm, Tsmo) to the west against Proterozoic rock to the east; southward it may merge with the Cerbat Mountain Fault, forming a scoop-shaped geometry (fig. 7; Faulds and others, 2010).

The Mockingbird Mine Fault bounds the east side of the Black Mountains at Mount Perkins, dipping gently eastward about 5 to 30 degrees. According to Faulds and others (1999), the fault has as much as $6 \mathrm{~km}$ of normal displacement, placing volcanic rocks (Tvm, Tbo) to the east against crystalline basement (Xg and Xgn) and the Mt Perkins pluton (Ti) to the west. Southward the fault loses displacement (fig. 7). Faulds and others (1999) interpret the central Detrital subba$\sin$ (fig. 2) as a west-tilted half graben in the hanging wall of the Mockingbird Mine Fault. Because the magnitude of west tilting decreases eastward across Detrital basin, Faulds and others suggest the Mockingbird Mine Fault steepens with depth. We suggest, as an alternative, the Mockingbird Mine Fault is cut by a range-front fault as discussed in the "inferred basin- fault" section below.

The Whipple Mountains detachment fault is interpreted by Howard and others (1999) to project from the Whipple Mountains (figs. 1, 4) northeastward beneath the Mohave and Buck Mountains. The fault is not exposed in the study area but inferred to extend to mid-crustal levels in the subsurface below the Hualapai Mountains and Colorado Plateau. According to this interpretation, the Mohave and Buck Mountains are west-tilted crustal blocks in the hanging wall of the detachment fault. The blocks are composed of crystalline basement (Xg) overlain by volcanic and sedimentary rocks (Tvo, Tsmo) tilted 30 to 80 degrees westward (Howard and others, 1999). The Crossman Peak Fault (fig. 6) is a low-angle fault in the hanging wall of the Whipple Mountains detachment that separates the Buck Mountains fault block from the main Mohave block (Crossman Peak block of Howard and others, 1999). The depth-to-bedrock model shows a low that wraps around the northeast end of the Buck Mountains (fig. 2). K.A. Howard (written commun., 2010) suggested that the gravity low could be caused by sharp density contrasts related to a buried synclinal corrugation in the Whipple detachment fault. On the geologic map of the Mohave Mountains, 
Howard and others (1999) tentatively inferred a north-northwest-striking fault between the Mohave and Buck Mountains (fig. 6) based on an abrupt change in gravity data that suggests a steeply dipping fault. This fault may cut the low-angle Crossman Peak detachment fault or the detachment fault may steepen with depth.

\section{Moderate- to High-angle Normal Faults}

The largest displacement high-angle normal fault in the area is the Grand Wash Fault, a west-side-down structure which forms the boundary between the Colorado Plateau and Basin and Range. The southern Grand Wash normal fault (fig. 6) extends north-northwest from the south end of the study area along Truxton Wash. Maximum displacement of more than $3 \mathrm{~km}$ on the southern Grand Wash Fault corresponds to the deepest part of the Hualapai basin (Faulds and others, 2008); the fault loses displacement both northward and southward. At the southern end of the study area, fault displacement is about $300 \mathrm{~m}$. The east-side down east Peacock Fault has a similar displacement amount and forms a graben with the Grand Wash Fault. The west Peacock Fault drops volcanic rocks down to the west into the Kingman subbasin. Older volcanic rocks (Tvo, Tto) exposed in the hanging wall dip into the fault and overlie crystalline basement. This implies another fault to the west that drops the section into the Kingman subbasin (fig. 2). The two Peacock faults may form part of a relay fault system that transfers slip between the down-to-the-west Grand Wash Fault and an unnamed east-side-down fault that bounds the east side of the Hualapai Mountains and increases in displacement south of the study area (fig. 6).

To the north, the southern Grand Wash Fault apparently dies out near the divide between Hualapai Valley and Hualapai Wash (fig. 1). This divide marks a point of minimum displacement on three intersecting faults (fig. 6). The northwest-side-down northern Grand Wash normal fault extends northeast from the intersection and forms the west boundary of the Colorado Plateau north of the study area. The west-side-down Lost Basin Fault extends north-northwest from the intersection, parallel to the strike of the southern Grand Wash Fault, and bounds the west side of the Lost Basin Range. The displacement on the Lost Basin Range may increase southward. The southern Gregg subbasin is located west of the intersection.

The northwest-side-down Cerbat Mountain Fault extends west-southwest from its junction with the Cyclopic Mine Fault through Dolan Springs and into Detrital Valley. Although previously inferred to continue southward along the west side of the Cerbat Mountains, recent geologic mapping suggests that south of Dolan Springs, the Cerbat Mountain Fault does not extend along the range front to the pass between Detrital and Sacramento Valleys (Ferguson and others, 2009), as has been inferred (Faulds and others, 2010). Similarly, a fault along the west side of the Cerbat Mountains north from Kingman appears to end near Chloride, south of the pass between the two valleys. Recent mapping by the Arizona Geological Survey (C.A. Ferguson, oral commun., 2009) suggests the divide between Detrital and Sacramento Valleys is underlain by a syncline, therefore, we project the Cerbat Mountain Fault south-southwest into Detrital Valley, where the fault is most likely cut by a younger north-northwest-striking fault. However, highly extended terrane and significant volcanism are confined west of a structural zone defined by the South Virgin - White Hills detachment Fault, the Cyclopic Mine Fault, and the Cerbat Mountain Fault, indicating that the Cerbat Mountain Fault is part of a significant but enigmatic tectonic boundary. We suggest that this enigmatic boundary crosses Detrital Valley, then turns southward, obscured along the many faults in the Grasshopper Junction area west of the divide (figs. 6,7), and extends south beneath the Black Mountains.

North and west of the Cerbat Mountain Fault, the west-side-down Mountain Spring Fault and the White Hills Fault cut consolidated sedimentary and volcanic rocks exposed in the White Hills. These rocks are part of the Miocene White Hills half-graben basin of Faulds and others 
(2010) that formed in the hanging wall of the Cerbat Mountain-Cyclopic Faults and was subsequently faulted and tilted and is now partially eroded. The Mountain Spring Fault separates the White Hills basin into an eastern, sediment-rich subbasin and a western, volcanic-rich subbasin. According to Faulds and others (2010), the fault has about $1 \mathrm{~km}$ normal separation in the south which increases northward to as much as 3 to $4 \mathrm{~km}$. Depth to basement models (Langenheim and others, 2010; this report), suggest a shallow basin here with about 400 to $500 \mathrm{~m}$ of probable sedimentary fill. The Mountain Spring Fault most likely links northward to the South Virgin - White Hills Detachment Fault. To the west, the smaller displacement west-side-down White Hills Fault has $\sim 1.2 \mathrm{~km}$ normal separation.

The Detrital Fault bounds the west side of northern Detrital subbasin and is defined by surface geology, well data, and seismic reflection profiles presented in Faulds and others (1999). The fault traces southward from Lake Mead and dies before the Black Mountains accommodation zone. The fault trace is marked by discontinuous scarps in a conglomeratic facies of the Tsy unit on the west side of Detrital Valley and possibly by a strong north-trending gravity and magnetic gradient along the west side of the valley (Langenheim and others, 2010). However, the Detrital Fault most likely loses displacement southward toward the subbasin divide, and so the gradients there may be due to strong bedrock density variations (Langenheim and others (2010).

The Blind Goddess Fault, as imaged on the seismic reflection profiles (Faulds and others, 1999), strikes north and dips west and is most likely a fairly small displacement fault that bounds the east side of Detrital Valley between the northern and central subbasins (fig. 2). The fault appears to either die out northward against or link to an unnamed fault that bounds the east side of the northern Detrital subbasin and displaces the Tsy and Tsh units down to the west. Interpretation of GEOTEM data (M. Truini, unpub. data, 2010) indicates the down-dropped block dips eastward into the northern fault, and Laney (1979) maps an anticline in outcrops of Tsh to the west of the fault, suggesting a hanging wall anticline. The Blind Goddess Fault appears to die out just south of the community of White Hills near the northeast margin of the southern Detrital subbasin.

Southward, we infer a fault or faults along the east side of the southern Detrital subbasin based on the depth-to-bedrock model and GEOTEM data. These structures, if they exist, die out north of the pass at Grasshopper Junction (figs. 6, 7).

\section{Inferred Basin Faults}

The subbasin configuration seen on the depth-to-bedrock model (fig. 2) suggests the presence of basin-controlling faults that are not expressed at the surface. We infer these structures based on the depth-to-bedrock model, well data, and projection of faults mapped in the bedrock (fig. 7).

\section{Hualapai Valley}

The depth-to-bedrock model (fig. 7) shows a sharp boundary at the southeast margin of the Kingman subbasin northeast of Kingman, interpreted here as the northeast-striking Kingman Fault. This inferred fault is collinear with the southeast edge of the paleovalley at Kingman. East-tilted rocks in the hanging wall of the west Peacock Fault indicate another west-side-down fault should be to the west. Whether that fault parallels the west Peacock Fault or is the inferred Kingman Fault is unknown. It is possible that a Laramide-age fault formed the southeast edge of the paleovalley that was then onlapped by volcanic rocks and reactivated. Therefore, the sharp northeast-trending edge to the basin may be a fault, a buried topographic feature, or both. 


\section{Detrital Valley}

A range-front fault is well-imaged on the seismic reflection profiles in Detrital Valley on the east side of the Black Mountains (Faulds and others, 1999) and forms the boundary to a west-tilted half-graben basin seen in the seismic profile as well as in the depth-to-bedrock model. This fault, called herein the South Detrital Fault (fig. 6), extends south-southeast and possibly steps westward (dotted trace in fig. 7), dying out at the southern end of Detrital Valley. This fault may cut or splay upward from the Mockingbird Mine Fault.

\section{Sacramento Valley}

We infer that several oppositely dipping normal faults control the subbasins of Sacramento Valley. South of Grasshopper Junction (figs. 6, 7), the west-side-down Chloride Fault bounds the east side of a small basin and extends southward along the range front from Chloride to west of Kingman, based on well data and the depth-to-bedrock model. To the west, the east-side-down Black Mountain Fault extends along the east side of the Black Mountains, forming a presumed west-dipping half-graben basin. The geometry of the faults and the shallow depth of bedrock extending north-northwest between the basins suggests a relay or anticlinal transfer zone between these faults. Well data and steep depth-to-bedrock contours suggest possible small displacement faults on the opposite sides of the half-graben basins. Alternatively, the steep contours could be an artifact of laterally heterogeneous rock densities between alluvial fans and fine-grained sediments (V.E. Langenheim, oral commun., 2010). The Black Mountain Fault continues southward to the tip of the Black Mountains, but the depth-to-bedrock model suggests decreasing displacement.

The north-northwest-trending Dutch Flat subbasin (fig. 2) suggests that a fault extends along the northeast side of the Buck and Black mountains. We map the subsurface Buck Mountains Fault as wrapping closely around the Buck Mountains and extending northward. Because the Buck Mountains are interpreted as a west-tilted fault sliver of crystalline rock in the hanging wall of the Whipple detachment fault (Howard and others, 1999), the shape of the depthto-bedrock anomaly may be influenced by the contrast between the crystalline rock and surrounding lower density material and therefore the fault could be more planar. In addition, because of the contrast in the bedrock gravity anomaly between Buck and Black Mountains, the shape of the fault and asymmetry of the basin anomaly is approximate at best. We suggest the north-northweststriking unnamed fault between the Buck and Mohave mountains extends beyond the southern tip of the Black Mountains. It may link to a fault or faults bounding the east side of a north-northwesttrending basin north of Topock indicated by the depth-to-bedrock model. If so, then the Buck Mountains Fault and the unnamed north-northwest-striking fault may be part of a fault zone linking the Dutch Flat basin to the Topock subbasin. This fault most likely dies out or splays northward into several faults that cut the southwestern tip of the Black Mountains, where west-dipping volcanic rocks are cut by north-northwest-striking faults.

A west-side-down fault on the southwest side of the McCracken Mountains (figs. 1, 7) appears to extend northward and control the northeast side of a smaller basin on the south end of Dutch Flat. It may step westward and link to the inferred north-northwest-striking Dutch Flat Fault, between the large Dutch Flat subbasin and the western edge of the shallow bedrock surface west of the Hualapai Mountains (figs. 2, 7).

\section{Accommodation zone}

The magnitude of extension in the Colorado River Extensional Corridor decreases both northward and southward into the Black Mountains accommodation zone (Faulds and others, 2001). The accommodation zone extends eastward across the Colorado River corridor and then 
turns southward along the east side of the Black Mountains (figs. 4, 6). The zone separates two oppositely tilted fault block domains, west-tilted fault blocks to the south and west, east-tilted fault blocks to the north and east. In the transverse part of the accommodation zone, east-dipping faults and west-dipping faults overlap to form a zigzag pattern defined by overlapping tips of oppositely dipping faults as the dip direction of faults and associated tilted fault blocks change (Faulds and others, 1999). The axis of the zone is therefore traceable by a series of fault-related folds caused by the reversal in dip direction of the major normal faults that intersect in the zone - anticlines where faults of opposite dip face each other, and synclines where they face away (Varga and others, 2004). Langenheim and others (2010) suggested shallow depth-to-bedrock, both in the central part of Detrital Valley and at the divide between Detrital and Sacramento Valleys, correspond to places where the accommodation zone crosses the valleys (fig. 7). However, the depth-to-bedrock model shown in figures 2 and 7 do not show a strong correspondence between the accommodation zone and shallow bedrock.

\section{Description of Subbasins Identified from Depth-to-bedrock Gravity Model}

In this section the geology of the subbasins is described; geologic characteristics of each basin are summarized in table 1. In the study area, the subbasins are either full grabens (such as fig. 3, Anning and others, 2006) or more commonly half-grabens, such as portrayed in figure 5. The half-graben basins are characterized by wedge-shaped sediment accumulations that develop on the tilted hanging wall of a large normal fault. The typical model of half-graben basin development is as follows: the basin forms by repeated displacement on the fault and the deepest part of the depocenter is usually close to the fault. Thick but areally restricted alluvial fans develop adjacent to the fault from detritus sourced from the footwall. In contrast, thinner but more widespread alluvial fans prograde from the uptilted edge of the hanging wall toward the fault and can interfinger laterally with the footwall fans. Most fine-grained material is deposited in axial fluvial systems that parallel the controlling fault, and in lakes or playas that develop along that part of the fault with the greatest displacement and therefore, the greatest subsidence.

\section{Detrital Valley}

Detrital Valley is an elongate north-south valley underlain by three subbasins that appear to be formed by a series of opposing half-graben faults (table 1). The northern Detrital subbasin is partly dissected by Detrital Wash so that some of the subsurface geology (Tsy; younger sedimentary basin-fill unit) is exposed near Lake Mead. In contrast, the two other subbasins, the central and southern Detrital subbasins, are buried beneath surficial deposits and the only information about subsurface geology comes from wells and geophysical data. The subsurface bedrock divides between the subbasins are most likely underlain by volcanic rock. The two northern subbasins include evaporite sequences in the younger basin fill deposits (Tsy); whether they occur in the southern subbasin is unknown. Known gypsum/halite deposits have been penetrated in three well clusters: (1) anhydrite and clay in the north part of the northern subbasin, (2) halite, anhydrite and clay in the southern part of the northern Detrital subbasin, and (3) gypsum, anhydrite and clay in the central subbasin. Gypsum/anhydrite mixed with clay and siltstone is also exposed as high as 500 to $580 \mathrm{~m}$ elevation on the east side of Detrital Wash just northeast of the second cluster of wells (Beard and others, 2007).

\section{Northern Detrital Subbasin}

The northern subbasin is modeled as about $600 \mathrm{~m}$ deep and is either a graben developed between an unnamed west side down normal fault to the east and the Detrital fault to the west, or 
an east-dipping half-graben controlled by the unnamed fault. The modeled shape of the basin is suspect because of the contrast in bedrock gravity anomaly between the Black Mountains and the White Hills to the east (fig. $3 C$ ). However, the half-graben model is supported by the presence of east dipping strata; east-dipping volcanic rocks and underlying crystalline rocks are exposed in the footwall of the unnamed fault on the west side of the White Hills (fig. 6). In addition, younger basin fill deposits (Tsy) in the hanging wall dip eastward into the fault.

The subsurface stratigraphy of the northern subbasin, immediately south and west of the east-dipping Tsy unit, can be correlated between wells. Here, a cluster of 7 wells (cluster \# 2 listed above; drilled from 1957 to 1959; Arizona Department of Water Resources unpublished archival data) penetrated unconsolidated alluvium, 60 to $90 \mathrm{~m}$ of "boulder conglomerate", 55 to $100 \mathrm{~m}$ of clay/anhydrite interval, and the top of a halite body. The top of the clay/anhydrite deposits is at $\sim 450 \mathrm{~m}$ elevation, indicating nearly horizontal stratigraphy at least near the top of the basin-fill deposits. If the subbasin is a half-graben, fanning dips must be at or below the halite horizon.

The top of the clay/anhydrite section in the well cluster at the north end of the northern subbasin, at about 380 to $310 \mathrm{~m}$ elevation, is lower in elevation than the clay/anhydrite/halite sequence farther south and varies by as much as $40 \mathrm{~m}$. The alluvial cover is less than $10 \mathrm{~m}$ thick, suggesting an eroded or beveled top to the basin-fill units where erosion has been deeper due to proximity of Detrital Wash to the Colorado River. A slight shallowing of the basin floor revealed in the depthto-bedrock model, the lower elevation of the top evaporite section, and the lack of halite suggest there may also be a low-elevation bedrock divide within the northern subbasin that divides the northernmost clay/anhydrite deposits from the main halite deposit to the south. At the far north end of the valley next to Lake Mead, evaporite and siltstone beds adjacent to the Black Mountains structural block dip eastward, but the dip may be related to uplift of the range block rather than half-graben formation.

Two wells west of the halite body and just east of Detrital Fault in the northern subbasin indicate less than a meter of unconsolidated alluvial material overlying a thin alluvial conglomerate unit, $\sim 10$ to $15 \mathrm{~m}$ thick, that in turn overlies as much as $270 \mathrm{~m}$ of interbedded sandstone, clay, and thin conglomeratic layers. The alluvial conglomerate unit is described in one well as cemented by carbonate, indicating it is most likely the QTa unit exposed to the south, which has a strong carbonate soil horizon. The fine-grained clastic deposits beneath are most likely marginal lacustrine basin-fill deposits that are laterally equivalent to the clay/anhydrite/halite sequence. However, because the wells are near the Detrital Fault scarps, it is possible these deposits are faulted against the clay/anhydrite/halite sequence instead. The fault scarps are coincident with the strong gravity gradient as described above for the Detrital Fault (Langenheim and others, 2010).

\section{Central Detrital Subbasin}

The depth of the central subbasin is uncertain: it has been estimated to be as much as 700 $\mathrm{m}$ deep for the depth-to-bedrock model in this report, $900 \mathrm{~m}$ deep by ADWR (Mason and others, 2007), 1 to $1.5 \mathrm{~km}$ deep by Langenheim and others (2010), and close to $2 \mathrm{~km}$ deep by Faulds and others (1999). The subbasin is a west-tilted half-graben that is well-imaged on a seismic reflection profile interpreted by Faulds and others (1999). The seismic profile trends northeast from Detrital Fault and reveals a wedge-shape basin, with fanning dips, that thins to the east as it approaches the White Hills. Well data indicate no more than about 200 to $300 \mathrm{~m}$ of gypsum, anhydrite and clay in the upper $600 \mathrm{~m}$ of the deeper part of the subbasin; consistent with the interpretation by Langenheim and others that the evaporite sequence is thin or doesn't contain significant halite ( $>$ $500 \mathrm{~m}$ ). The top of the evaporite/clay sequence is at about 560 to $580 \mathrm{~m}$. Several wells on the east side contain gypsum and clay, with minor consolidated conglomerate, and penetrate granite 
at about $400 \mathrm{~m}$ depth, consistent with the thinner part of the wedge shape basin. The upper $200 \mathrm{~m}$ of section on the east side are generally coarser sand and gravel alluvial deposits that are locally thicker because of a large alluvial fan that extends westward from the White Hills. The central Detrital subbasin is not as well defined on the depth-to-bedrock model as the subbasins to the north and south. Lateral density changes related to the large alluvial fan may be influencing the basin shape and depth. The Blind Goddess Fault on the east side of the basin does not seem to control the basin geometry.

\section{Southern Detrital Subbasin}

The depth-to-bedrock model presented in this report and from ADWR (Mason and others, 2007), Langenheim and others (2010) all indicate that a north-south elongate subbasin underlies southern Detrital Valley. The model presented in this report suggests about $1500 \mathrm{~m}$ of basin fill deposits, similar to the modeled 1000 to $1500 \mathrm{~m}$ depth by ADWR but much less than the $3500 \mathrm{~m}$ depth indicated by Langenheim and others (2010). The basin is most likely an east-tilted half-graben bounded by an unnamed fault on the east. Well logs indicate the upper 300 to $400 \mathrm{~m}$ are clastic sediment, including sand and gravel and interlayered fine-grained clay, silt and sand units that are as thick as $\sim 100 \mathrm{~m}$. However, no wells are deeper than $400 \mathrm{~m}$. Consequently the material in the lower part of the subbasin is unknown.

A shallow subsurface bedrock bench extends east of the deeper subbasin to the range front. The bench lies at 400 to $\sim 800 \mathrm{~m}$ depth below the alluvial surface of the valley. Well logs indicate as much as $200 \mathrm{~m}$ of volcanic rock overlying crystalline basement. A few meters to $\sim 100 \mathrm{~m}$ or more of alluvial fan deposits overlie the volcanic rocks. The valley west of the subbasin is underlain by relatively thin alluvial fan deposits overlying a possible pediment surface developed on crystalline rock. The crystalline bedrock surface deepens eastward into the valley, either because of tilt into the inferred half-graben or because of offset by a possible southward extension of the south Detrital Fault. The age and type of deposit in the deeper part of the subbasin are unknown.

\section{Hualapai Valley}

The three subbasins of Hualapai Valley are dissimilar in shape and possibly genesis (table 1). The larger Hualapai subbasin is a northwest elongate, northeast-tilted half-graben structure controlled by the southern Grand Wash Fault. It includes a $2.5 \mathrm{~km}$ thick deposit of halite, anhydrite and clay (Faulds and others, 1996). East of the inferred trace of the Grand Wash Fault, the Grand Wash Cliffs are deeply embayed and a short alluvial fan surface extends about 4 to $5 \mathrm{~km}$ west from the cliff face. West of the subbasin, the Cerbat Mountain block with its thin cover of older volcanic rocks (Tvo) dips about 20 degrees eastward toward the Grand Wash Fault and probably projects eastward as the floor of the Hualapai subbasin. Basin-fill sediments of the Hualapai subbasin have a wedge-shape, with the thin part of the wedge lapping onto the Cerbat Mountain block.

The southern Gregg basin is a northward continuation of Hualapai subbasin, separated by a deep subsurface bedrock divide whose genesis is poorly understood.

The south side of Hualapai Valley is underlain by the Kingman subbasin, which has special significance as the source of Kingman's water. The shallow subsurface below the alluvial valley southeast of the deepest part of the subbasin is a broad pediment overlain by young alluvial deposits (Qa) and older, more consolidated alluvial fan deposits (QTa).

A northeast-trending structural divide underlain by crystalline bedrock separates the Kingman and Hualapai subbasins, marked by up to $500 \mathrm{~m}$ of local relief from the low point of the divide to the top of Long Mountain. Sediment at the divide is mostly fine-grained clastic strata overlying crystalline rock and is no more than $200 \mathrm{~m}$ thick. The divide coincides with a sharp 
$60 \mathrm{~m}$ northward decline in water level contours (Anning and others, 2007) between the two subbasins. A few wells suggest the local presence of a thin unit of buried volcanic rock west of Long Mountain, consistent with exposures of volcanic rocks on the west side of Long Mountain and the east side of the Cerbat Mountains. Correlative volcanic rock is also mapped as deposited on basement at the east end of Long Mountain.

\section{Hualapai Subbasin}

The depth-to-bedrock model indicates that the Hualapai subbasin is about 4 to $4.5 \mathrm{~km}$ deep. The $600 \mathrm{~m}$ or more of upper basin fill are most likely equivalent to surficial deposits (Qa, QTa, Qp, Qpo) overlying younger sedimentary rocks (Tsy). Below this unit, drill cores and seismic data indicate that $\sim 2.5 \mathrm{~km}$ of halite makes up much of the subbasin fill (Faulds and others, 1997). Using

seismic data, Faulds and others (1997) infer that the halite deposits interfinger laterally eastward with fanglomerate units derived from the Grand Wash Fault. They suggest the age of this part of the sedimentary fill in the Hualapai half-graben basin is about 9 to $13 \mathrm{Ma}$, comparable to the age of the halfgraben basin fill of the Grand Wash trough to the north of the study area (and equivalent to Tsmy).

Faulds and others (1997) interpret the section below the halite and associated deposits (Tsmy) to include about $335 \mathrm{~m}$ of younger volcanic rocks (13-15 Ma; Tvy) overlying $750 \mathrm{~m}$ of older volcanic rocks and minor sedimentary rocks (Tvo, Tso) deposited on Cambrian strata. This lowest part of the interpreted section (Tvo, $€ \mathbf{b t}, € \mathbf{\epsilon})$ matches the exposed section along the edge of the Grand Wash Cliffs and is therefore the down faulted hanging wall of the Grand Wash Fault. However, because the older sedimentary and volcanic rocks are not widely distributed on the Grand Wash Cliffs but rather fill paleovalleys, some of the 750-m-thick section is most likely Devonian Temple Butte Formation (Dtb) and possibly Mississippian Redwall Limestone (Mr). In addition, the Try section is not exposed on either side of the Hualapai subbasin. Therefore, the inferred Tvy section must have been either deposited during or after displacement along the Grand Wash Fault, eroded from the exposed part of the Cerbat Mountain block, or never deposited in the basin.

The deepest part of Hualapai subbasin extends southeast from Red Lake playa. The playa is fed by sediment from (1) Truxton Wash off of the Colorado Plateau and (2) Frees Wash, which drains through the Kingman subbasin. The ephemeral Truxton Wash has a 1-3 m deep alluvial channel where it flows along the trace of the concealed Grand Wash Fault. Northward towards the modern playa the wash forms a very low-gradient braidplain of undissected sand to sandy gravel. Local ponded areas of silt and clay form hard pan surfaces within the braidplain. Frees Wash is an ephemeral stream bed that is floored by fine-grained sand and silt. Both washes have low gradients in their down-stream reaches such that sediment-laden floodwaters probably do not reach the playa except during very large floods.

Extensive cracks or earth fissures pervade the surface of the Red Lake playa (Neal and Motts, 1967; Neal and others, 1968; Lister and Secrest, 1985). According to Lister and Secrest (1985) the entire modern playa surface is or has been fissured, and the older, partially covered playa surface is also cracked. They describe two distinct systems of cracks and attribute them to two separate processes: (1) a large polygonal crack pattern formed by deep-seated desiccation and (2) a ring-fissure system on the south side of the modern playa attributed to local subsidence. Proprietary seismic sections indicate that there is considerable relief on the top of the salt body (Federal Energy Regulatory Commission, 1982), and the ring fractures are associated with a low in the top of the salt body. The authors suggest the relief on the salt body is due to salt flowage, perhaps in response to faulting, sediment loading, or both.

The extent of the surface playa was larger during the Pleistocene (Qpo), as suggested by the limit of the older Truxton Wash alluvial fan (Qto). The subsurface extent of the subbasin is larger 
than the Pleistocene playa, according to Ivanich and Conway (2009). Coarser alluvial fan deposits extend west from the Grand Wash Cliffs and interfinger with the fine-grained clay and silt playa deposits on the margins of the playa; the position of these fans relative to the playa margin has probably not changed much from the Pliocene although interpretation of the GEOTEM data (M. Truini, unpublished data, 2010) suggests some limited progradation of coarser material out onto the playa. The west side of Hualapai Valley is an east-sloping pediment developed on volcanic and crystalline rocks.

\section{Kingman Subbasin}

The Kingman subbasin is one of the most enigmatic because, as discussed above, the northeast-trending southern edge to the basin may be the inferred Kingman Fault, a buried topographic feature, or both. The depth-to-bedrock model suggests the subbasin is about $1.2 \mathrm{~km}$ deep. It lies directly northeast of the early Cenozoic paleovalley exposed at Kingman, and therefore most likely has at least 100 to $200 \mathrm{~m}$ of older volcanic rocks, including Tvo and Tto, in the subsurface. A similar paleovalley is well preserved at Truxton in the footwall of the Grand Wash Fault; assuming they are the same paleovalley, it is most likely in the subsurface between Kingman and the Grand Wash Cliffs. If the paleovalley extended directly between the two locations, the south edge of the Kingman subbasin could be a faulted edge of the paleovalley. Farther east, faulting on the east side of the Hualapai Mountains and the east and west sides of the Peacock Mountains most likely have disrupted and obscured it.

Volcanic rocks occur in wells in the west part of the subbasin and are overlain by sediments, locally including as much as $170 \mathrm{~m}$ of silt, sand and clay. A well, east of the Kingman Airport (ADWR database; 55-903521) logged by Montgomery and Associates, penetrated almost 500 $\mathrm{m}$ of granitic-composition alluvial sediments. Volcanic rocks are here inferred to underlie sediments penetrated in this and other shallower wells, but their depth, thickness, and lateral extent in the deeper part of the subbasin is unknown. Volcanic rocks on the southeast flank of the Cerbat Mountains dip moderately southeastward and the Kingman subbasin may be a southeast-tilted halfgraben bordered by the Kingman Fault.

\section{Southern Gregg Subbasin}

The southern Gregg subbasin models to about $1.4 \mathrm{~km}$ deep and shallows only slightly southward toward a poorly defined buried divide with the Hualapai subbasin. Well data indicate the upper $400 \mathrm{~m}$ or more is fine- to medium-grained clastic sediment. The Hualapai Limestone (Tsh) is found as far south as the southern tip of Lost Basin Range, where a well log shows 20 to 30 $\mathrm{m}$ of limestone overlain by a 10 -m-thick clay and sand layer, with some gravel, followed by coarser alluvial wash and fan deposits (Tg, QTa, Qa, Qw). The clay, sand and gravel layer is also seen in at least one well to the north and is most likely the same unit that is exposed at the top of the Hualapai Limestone in an unnamed wash to the north on the east side of the White Hills (deposits of Hualapai Wash, Faulds and others, 2008). The Hualapai Limestone is exposed from this wash north to Lake Mead. The unit is tilted eastward in a hanging wall anticline toward, and truncated by the Lost Basin Fault. Well data to the south and interpretation of the GEOTEM data (M. Truini, unpub. data, 2010) suggests the limestone thins southward and interfingers with clastic rocks.

Structural controls of this subbasin are poorly understood. Faulds and others (2008) suggest the chief control of basin formation is a displacement gradient on the Grand Wash Fault. An east-side-down fault is inferred along part of the west side of the basin based on the steepness of the depth-to-bedrock gravity model (fig. 7). The east side of the northern part of the subbasin is most likely controlled by increasing displacement southward on Lost Basin Fault which herein is 
inferred to terminate against the westward tip of the Grand Wash trough and thus form the southeast edge of the southern Gregg subbasin (figs. 6, 7).

\section{Sacramento Valley}

Sacramento Valley basin includes, from north to south, the Chloride, Golden Valley, and Dutch Flat subbasins (table 1, fig. 7). The northern two appear to be half-graben basins with opposed tilt directions, separated by a narrow subsurface high. The Golden Valley and Dutch Flat subbasins are separated by a $\sim 20 \mathrm{~km}$ long stretch of shallow volcanic and crystalline bedrock.

The east side of Sacramento Valley is a pediment in which shallow bedrock extends 8 to $10 \mathrm{~km}$ westward from the Hualapai Mountains range front before dropping off into the deeper part of the subbasins. Alluvial-fan sediments veneering the pediment are mostly medium- to coarsegrained sands and gravels composed mostly of crystalline rock detritus but also locally including volcanic detritus near Kingman; where sourced from granitic rocks the deposits are least coarse (grusy). The deposits are mostly unconsolidated and mapped as the Qa unit, but the subsurface probably includes consolidated QTa and possibly Tg deposits. Sediment thickness on the pediment is typically about 20 to $50 \mathrm{~m}$ but varies up to a maximum of about $200 \mathrm{~m}$. West of Kingman, the pediment is locally developed on volcanic rocks that dip westward into the Golden Valley subbasin or on Proterozoic crystalline rocks. Southward, Proterozoic crystalline rocks underlie the pediment surface. The volcanic and crystalline rocks are exposed in isolated hills surrounded by alluvial fan deposits, almost exclusively derived from Proterozoic crystalline rocks.

Although not expressed in the depth-to-bedrock gravity model, well logs and GEOTEM data (M. Truini, unpub. data, 2010) suggest an enigmatic small buried valley either under or cut into the pediment in the foothills of the Hualapai Mountains (fig. 7; red dashed fault east of Dutch Flat Fault). This feature may be a small fault-controlled subbasin or a paleovalley filled with volcanic rocks and capped by the pediment gravels.

A $20 \mathrm{~km}$ long narrow zone of shallow depth-to-bedrock that connects the deeper Golden Valley and Dutch Flat subbasins lies between the Black Mountains and the pediment surface (fig. 2). The west side of the zone coincides with the Black Mountains Fault. Well logs and the GEOTEM data (M. Truini, unpub. data, 2010) indicate the crystalline basement is overlain by about 80 to $100 \mathrm{~m}$ of volcanic rock, which in turn is overlain by clastic sediments.

The extent of fine-grained Bouse Formation sediments (Tsb) northward in Sacramento Valley is unknown. Surface outcrops occur from Topock to the junction of Buck Mountains and Sacramento Washes. Although well data and GEOTEM interpretations (M. Truini, unpub. data, 2010) indicate fine-grained sediments in the Golden Valley subbasin, it is not clear whether (1) the Bouse basin physically extended that far north, (2) Golden Valley subbasin was a separate basin but the same age as the Bouse, or (3) the fine-grained sediments are part of an older basin. The regional top of the Bouse deposits is about $550 \mathrm{~m}$ (P. Pearthree, written commun., 2009). Where the $550 \mathrm{~m}$ topographic contour intersects Sacramento Wash (the highest potential Bouse outcrop), the depth-to-bedrock model suggests the top of the bedrock is at $500 \mathrm{~m}$ elevation, just $50 \mathrm{~m}$ below the surface. A well located just east of this point penetrated $70 \mathrm{~m}$ of "clay" (ADWR well 55-204031) from $\sim 570$ to $500 \mathrm{~m}$ elevation. Therefore, it is permissible that the Bouse depositional environment could have extended into the Golden Valley subbasin through this gap. Bouse sediments could also be in the subsurface of the southern part of Sacramento Valley, along Buck Mountains Wash, and in the Dutch Flat subbasin. 


\section{Chloride Subbasin}

The Chloride subbasin, bounded on the east by the subsurface Chloride Fault, models to $\sim 900 \mathrm{~m}$. Wells indicate at least $750 \mathrm{~m}$ of clay, sand and some granitic gravel fill. The upper 200 $\mathrm{m}$ or so are coarser alluvial deposits. The sediments in the lower part of the basin, based on their fine-grained character, are most likely equivalent to fine-grained clastic rocks of the younger sedimentary rocks (Tsy) or possibly the intermediate-age sedimentary rocks (Tsmy). Wells in Chloride subbasin and at the north end of the Golden Valley basin have warm temperatures up to 39 degrees $\mathrm{C}$, suggestive of relatively deep water circulation, perhaps along faults controlling the subbasins. East of the Chloride Fault, about 50 to $60 \mathrm{~m}$ of coarse alluvial fan deposits derived from crystalline basement rocks overlie a pediment developed on crystalline basement. The Chloride subbasin is most likely an east-tilted half-graben although the west side may also be fault-controlled, suggesting a graben. Alternatively, the relatively steep west margin suggested by the depth-to-bedrock gravity model may be an artifact of changing rock densities, from coarse alluvial fan to finegrained deposits.

The depth-to-bedrock gravity model indicates a shallow fill about 200-300 m thick connects the northern end of Sacramento Valley northward with Detrital Valley. This is probably underlain by a syncline in the volcanic rocks between the Cerbat and Black Mountains rather than a fault with any significant displacement. The fill above the volcanic rocks is most likely coarse-grained alluvial-fan sediments with an axial zone of finer grained axial wash material.

\section{Golden Valley Subbasin}

Golden Valley is underlain by an elongate subbasin as much as $1.3 \mathrm{~km}$ deep (Langenheim and others, 2010) and is controlled by the Black Mountain Fault on the west. This subbasin is interpreted as a west-dipping half-graben by Langenheim and others (2010) although seismic data (Faulds and others, 1999), suggest the subbasin may be more symmetric. Exposures of west-dipping volcanic rocks on the east side of the valley, coupled with interpretation of the GEOTEM data (M. Truini, unpub. data, 2010) indicate that the subbasin is most likely floored by a west dipping sequence of volcanic rock about $500 \mathrm{~m}$ to $1 \mathrm{~km}$ or more thick (Tvo, Tto, Tvm). The volcanic rocks are overlain by medium to fine-grained sediments that are probably equivalent to the finegrained clastic deposits of the Tsy unit. Data from wells in the middle of the subbasin suggest interlayering of clay and silt deposits with coarser sand and gravel, indicating the sediments transition laterally into coarser alluvial fan deposits toward the basin margins. The alluvial fan deposits are derived mostly from volcanic rock to the west, and from mixed volcanic and crystalline to the east. There is no suggestion from the wells of evaporite or halite deposits, and most of the well logs indicate that the upper 200 to $300 \mathrm{~m}$ are clay mixed with silt, sand, and (or) gravel. These are interpreted as fine-grained wash sediments deposited along ancestral Sacramento Wash $(\mathbf{Q w})$ interfingering laterally with medium- to coarse-grained alluvial fan deposits (Qa, QTa). As discussed above, some of the fine-grained sediments could be equivalent to the Bouse Formation.

\section{Dutch Flat Subbasin}

The north-northwest- trending subbasin imaged on the depth-to-bedrock model that extends from the south end of Black Mountains to the southern end of Sacramento Valley is modeled as $2600 \mathrm{~m}$ deep. The subbasin has a shallow bedrock rim that separates the deep part of the subbasin from a smaller one to the south-southeast that is bounded by a west-side-down fault on the SW side of the McCracken Mountains. Little is known about this subbasin; wells penetrate no more than about $200 \mathrm{~m}$ depth and are logged as penetrating sand and gravel sediments with some thin ( 3-10 $\mathrm{m}$ thick) fine-grained clay layers, most likely the Qa, QTa, and possibly Tg deposits. The 
fine-grained layers could be Bouse Formation, or axial wash deposits $(\mathbf{Q w})$. One well $\log$ in the center of the subbasin anomaly recorded decomposed granite at $\sim 200 \mathrm{~m}$; it is not known if this is decomposed granite bedrock or a granite-sourced coarse alluvial deposit.

The Dutch Flat subbasin is interpreted here to be controlled by either the Buck Mountains Fault on the SW side or by the inferred Dutch Flat Fault on the northeast side. Although we suggest the subbasin is a west-tilted half-graben or a modified half-graben with the larger displacement fault on the southwest side, the contrast in bedrock gravity values between the Buck Mountains and Hualapai Mountains limits interpretation based on the shape of the basin anomaly.

\section{Geologic History}

Metamorphic gneisses and schists (Xgn) and granites (Xg, Yg) are the predominant Paleoproterozoic and Mesoproterozoic rocks in the map area. The rocks have undergone metamorphism and deformation, and subsequent intrusion. They are part of the Mohave crustal province as defined by $\mathrm{Pb}$ isotopic signatures (Duebendorfer and others, 2001). The boundary between the Mohave province and the Yavapai province to the east is a complex 75-km-wide isotopically mixed zone that strikes north-northwest (Wooden and DeWitt, 1991). Duebendorfer and others (2006) propose that the boundary zone was formed by rifting prior to juxtaposition and deformation of the two provinces. They suggest that a north-trending rift basin margin could underlie Hualapai Valley, on the basis of isotopic, geochemical, metamorphic and geophysical anomalies.

Paleozoic sedimentary rocks, exposed only along the Grand Wash Cliffs and the north end of Hualapai subbasin, are marine and continental deposits formed on the continental shelf of western North America. They include limestone, dolomite, sandstone, siltstone, claystone, and minor evaporite ( $\mathbf{E b t , ~} \mathbf{€ m}, \mathbf{D t b}, \mathbf{M r}, \mathbf{P M s}, \mathbf{P h}, \mathbf{P k t})$. These rocks are not present in the basins of the study area and are therefore not significant aquifer rocks. Although they originally extended across the study area, later erosion has removed them. Similarly, although Mesozoic sedimentary rocks are exposed to the north and east, there are none in this part of the Colorado Plateau or Basin and Range. They were also most likely stripped away by erosion.

To the north and west, the Early to Late Cretaceous Sevier orogeny resulted in a northnortheast-trending belt of southeast to east-vergent thrust faults, extending from western Montana to eastern California. In Late Cretaceous to Paleocene (Laramide) time, the study area was uplifted, exposing basement rocks in the core of the uplift. Faulds and others (2001) suggested that the early Cenozoic, north-plunging basement-cored Kingman uplift (Kingman uplift of Goetz and others, 1975; Kingman Arch of Bohannon, 1984) may have existed where the Black Mountains are now, separated from the Cerbat and Hualapai Mountains by a Laramide-age west-dipping reverse fault. Although such a fault has not been identified, it would have formed the boundary between the Lost Basin Range-White Hills- Black Mountains and the Cerbat and Hualapai Mountains (fig. 4).

Late Cretaceous to Early Tertiary intrusive rocks include 64 to 73 Ma two-mica, garnetbearing plutons in the Black Mountains and White Hills that were intruded as much as $10 \mathrm{~km}$ deep in the core of the Kingman uplift, and similar age plutons in the Cerbat and Hualapai Mountains and along the Grand Wash Cliffs that were intruded at shallower depths (Ki; Faulds and others, 1999).

Post-Laramide erosion removed Paleozoic and Mesozoic sediments off the Kingman uplift and created a beveled erosion surface cut on the lower and middle Paleozoic rocks of the western Colorado Plateau margin. The erosion was accompanied by the formation of large paleovalleys that drained northeast off the Kingman uplift and onto the Colorado Plateau (Young, 2001), including the paleovalley between the Cerbat and Hualapai Mountains, where the city of Kingman is located. 
Volcanism began $\sim 22 \mathrm{Ma}$, manifested by eruption of mafic flows, breccias, vents, and small stratovolcanoes, and local silicic domes and flows (Tvo). This was followed by caldera formation and deposition of the Peach Spring Tuff and associated deposits (Tto) at 18.5 Ma. The ash-flow tuff erupted from the Silver Creek caldera on the west side of the Black Mountains (fig. 4; Pearthree and others, 2009), and forms a regional marker unit that filled lower topography and paleovalleys such that its distrubution today outlines these paleotopographic features. The ashflow tuff unit is most likely in the subsurface in Sacramento Valley between the Black Mountains and Kingman and in Kingman Valley east of Kingman, perhaps confined to a paleochannel like that seen at Kingman.

Extension, accompanied by continuing volcanism, began at the far south of the study area at about $21 \mathrm{Ma}$, reached the latitude of Kingman by about $16 \mathrm{Ma}$, and reached Lake Mead by about $13 \mathrm{Ma}$ (fig. 2; Faulds and others, 2001). The earliest extension impacted only the area southwest of the Black and Hualapai Mountains; the older volcanic rocks in the southern Black Mountains are only mildly tilted, in contrast to similar age rocks to the south and west in the hanging wall of the Whipple detachment fault.

Large-magnitude extension confined to the Colorado River extensional corridor was typically predated by volcanism that began 1-2 my prior. Volcanism to the south began before $\sim 20 \mathrm{Ma}$ and culminated in the eruption of the Peach Springs Tuff and associated deposits from the Silver Creek caldera near Oatman (Pearthree and others, 2009), followed by outpouring of mesa capping basalts by $15.8 \mathrm{Ma}$ (Gray and others, 1990). Following caldera eruption, the loci of volcanism migrated northward to the central Black Mountains and included rhyolitic and andesitic volcanic fields, mostly west of the Cerbat Mountains. This volcanism ended with capping basalt flows that are less tilted than underlying rocks. The basalt was erupted at about 14 to $15 \mathrm{Ma}$ in the southern and central Black Mountains, and about at $12 \mathrm{Ma}$ to the north.

The main extensional event started at about $16 \mathrm{Ma}$ and peaked at about 15 to $13 \mathrm{Ma}$; extension affected most of the study area from north of the Silver Creek caldera to Lake Mead and resulted in highly tilted fault blocks. Lesser extension ("basin-range" faulting of Lucchitta and Suneson, 1994), characterized by high-angle normal faults, minor tilting, formation of narrow elongate basins, and minor basaltic volcanism, continued until about $8 \mathrm{Ma}$ (Lucchitta and Suneson, 1994; Faulds and others, 1999).

Intrusive bodies related to the volcanism are exposed locally (Ti). Extensional basins were filled by both volcanic and sedimentary rocks (Tvm, Tbo, Tsmo, Tsmy). In the northern White Hills the basins are predominately clastic, but in the southwest White Hills and the Black Mountains the fill is predominately volcanic. Most of these basins were internally faulted, and the older volcanic and sedimentary basin deposits are tilted from $\sim 30$ to as much as 90 degrees, as now exposed in the White Hills and Black Mountains.

Continued faulting formed full- and half-graben basins that now underlie the three major valleys. Sedimentary basin units in the northern part of the study area include fine-grained clay, silt, gypsum and halite deposited in a playa/lake environment, as well as sandstone and conglomerate eroded from the nearby ranges and deposited in marginal lacustrine and alluvial fan environments. These include deposits of the Miocene Muddy Creek Formation and similar age units (Tsy). The Hualapai Limestone, (Tsh) exposed in Hualapai Wash and westward toward Detrital Wash, is a carbonate lake facies, probably fed by springs (Pearce, 2010). To the south, the lake deposits of the Bouse Formation (Tsb) were deposited along what is now the valley of the Colorado River and extended some distance into Sacramento Valley. Fine-grained clastic rocks in the northern part of Sacramento Valley are inferred from well data and interpretation of GEOTEM data (M. Truini, unpub. data, 2010). Basin fill deposits in Hualapai Valley determined from well and seismic data include a $2.5-\mathrm{km}$-thick salt body overlain by fine-grained clastic deposits (Faulds 
and others, 1997). The fine-grained playa and lake deposits interfinger laterally with coarse clastic rocks deposited in alluvial fans fed from the Grand Wash Cliffs and Hualapai Mountains, as well as by Truxton Wash.

After $6 \mathrm{Ma}$, the Colorado River began downcutting and tributaries were formed, including Hualapai, Detrital, and Sacramento Washes. Sand and fine gravel is being transported along washes $(\mathbf{Q w})$, and alluvial fans and alluvial plains have prograded outward from the range fronts (QTa, Qa, Qto, Qty). Red Lake remains an internally drained basin with an active playa. Clay and sand are transported onto the surface by floods and reworked into eolian sandsheet and dune deposits (Qpo, Qpy, Qe).

\section{Acknowledgments}

The authors thank Dave Anning, and Marilyn Flynn of the U.S. Geological Survey Arizona Water Science Center for innumerable and insightful conversations on the geohydrology of Northwest Arizona. Keith Howard and Ernie Anderson provided thorough and thought-provoking peer reviews; we also thank Debra Block for the digital review of the digital geologic database. Sue Priest graciously helped with the aftermath of the digital review and preparation for publication.

\section{DESCRIPTION OF MAP UNITS}

Qdl Disturbed land-Areas where major excavation or filling has disturbed the land surface to the extent that its pre-existing geology is obscured

\section{SURFICIAL DEPOSITS (QUATERNARY AND PLIOCENE)}

Qa Younger alluvial fan, alluvial plain and pediment deposits (Holocene to late Pleistocene) - Alluvial fan and alluvial plain deposits originating on valley sides and in ranges and terminating at axial washes $(\mathbf{Q w})$. Locally includes talus deposits where mapped against the range front. Comprised of sand and gravel composed mostly of fragments of gneiss, schist and granitic rocks in sandy matrix, except areas near outcrops of volcanic rocks, where coarser fragments are composed of dominantly volcanic rock

Qp Active playa deposits (Holocene) - Mostly clay at surface, with subordinate silt and fine sand, deposited on active or recently active (within a few decades) playa of Red Lake. Surfaces are flat, prone to flooding, and devoid of vegetation. At margins of playa, flat surfaces may be surrounded by low sandy mounds that are likely eolian in origin. Clay is variably calcareous, micaceous, silty, and (or) salty (Asher-Bolinder and others, 1979). Locally includes small sand and fine-gravel size clasts of crystalline rocks probably brought in by floods. Mud cracks occur, but tend to be filled or healed because of occasional flooding

Qty Truxton Wash alluvial fan deposit, younger (Holocene) — Sand and sandy gravel, composed dominantly of crystalline-rock clasts with variable amounts of volcanic rock or lower Paleozoic quartzite and carbonate, deposited by Truxton Wash. Deposit grades to modern playa; overlies older playa deposits. Spreads from confined channel of Truxton Wash to alluvial fan geometry when floods reach very shallow to flat gradient of playa

Qw Axial alluvial wash deposits (Holocene) - Loose, fine-grained sediment, including mud, silt and sand with minor gravels, deposited in main washes 
that are axial to the valley basins. These include Detrital, Hualapai, Kingman, Sacramento, and Truxton Washes. Can include some coarse gravel locally near headwaters or where active alluvial fan or alluvial plain intersects washes. Characterized by anastomosing ephemeral washes, low relief interfluves, and minor eolian sand deposits

Qe Eolian sand deposits (Holocene to late Pleistocene)-Mapped on east side of Red Lake playa, in channels of the Truxton Wash alluvial fan, and eastward at base of Grand Wash cliffs. Near Red Lake, aerial imagery and topographic map bases suggest the presence of arcuate sand dunes, field inspection shows arcuate shapes are formed by alternating flat clay/silt pans and slightly coarser, vegetated areas. Tentatively interpreted as original sand dune fields from which the eolian sand was subsequently stripped away, with only vegetation bands marking original position of dunes

Qpo Older playa deposits (Pleistocene) - Clay, silt and sand forming deposits of inactive playas on south and east side of Red Lake at higher elevation than modern playa $(\mathbf{Q p})$; probably represent higher stand of playa during Pleistocene wet periods or possibly northwest migration of the depocenter. Inset by and/or overlain by younger alluvial fan and axial wash deposits (Qty, Qw). Surface is marked by extensive mud cracks. The cracks range from thin polygonal chips of 5-30 cm wide to giant (few tens of meters) polygonal cracks that are as much as $10 \mathrm{~cm}$ deep (Lister and Secrest, 1985). Cracks tend to be wide and open, locally vegetated

Qto Truxton Wash alluvial fan deposit, older (Pleistocene) - Mostly sand and sandy gravel, composed dominantly of crystalline rock with variable amounts of volcanic rock or lower Paleozoic quartzite and carbonate, with well-developed soil horizon deposited by older alluvial fan of Truxton Wash. Incised about 1 to $3 \mathrm{~m} \mathrm{(3} \mathrm{to} 10 \mathrm{ft}$ ) by younger Truxton Wash drainage. Interpreted as graded to older higher level playa deposits (Qpo)

QTa Older alluvial fan, alluvial plain, and pediment deposits (Pleistocene to upper Pliocene) - Highly dissected older alluvial fan deposits, composed of sand and gravel. Dissection forms ridges that display rounded profiles, commonly with degraded or eroded soil profiles exposed on surfaces. In northwest Detrital Valley, includes a thick carbonate soil horizon, up to $2 \mathrm{~m}$ (6 ft) thick. Mostly crop out in isolated deposits near or at range fronts

QTI Landslide deposits (Pleistocene to upper Pliocene) - Unconsolidated to partly consolidated masses of rubble and brecciated blocks of rock that have collapsed down slope from cliffs. Includes landslide masses mantling cliffs of Hualapai Limestone along Lake Mead, and one large landslide mass of volcanic rocks at Grand Wash Cliffs (Billingsley and others, 2006)

Tg Gravel deposits (Pliocene)-Isolated outcrops of sand and gravel deposits, more intensively dissected and topographically higher than older alluvial fan deposits (QTa). Age inferred to be Pliocene. Mostly conglomeratic alluvial deposits, but includes Pliocene Colorado River deposits near Lake Mead and near the Colorado River in the lower reach of Sacramento Wash. Conglomeratic alluvial deposits are poorly dated; most likely represent a sequence of alluvial fans that prograded over the regional top of basinfill deposits such as Tsy. This progradation is inferred to have occurred as a consequence of the shift from closed-basin to open-basin deposition 
characterizing establishment of the Colorado River and its tributaries. Crops out in Detrital Valley and in isolated exposures on the flanks of the Hualapai Mountains but probably much more extensive in the subsurface

\section{CONSOLIDATED BASIN-FILL DEPOSITS (PLIOCENE, MIOCENE, AND OLIGOCENE)}

Tsb Bouse Formation (Pliocene and upper Miocene)-Mostly fine-grained white to buff sand, silt, and clay (Howard and others, 1997), partly to mostly consolidated. Locally includes basal marl. Only exposed in western Sacramento Valley, near east-west stretch of Interstate 40. As mapped, includes locally calcareous white fine-grained sand and silt of uncertain affinity that crops out both north and south of Interstate 40 . Inferred by Pearthree and others (2009) to be a facies of the Bouse, or possibly related to an early Pliocene Colorado River floodplain deposit. Eastward and northward, the calcareous sand and silt beds grade laterally and upward to gravelly sandstone and conglomerate toward the southern tip of Black Mountains, where coarser material is mostly sourced from volcanic rocks exposed in Black Mountains, but includes some crystalline clasts.

May extend in subsurface into upper Sacramento Valley. In subsurface of Mohave Valley to west of study area, includes thin lower clastic limestone unit, and an upper section of shale and siltstone that grades upward into interbedded sandstone and siltstone. Basal marl is thin bedded white marly limestone, about 1 to as much as $8 \mathrm{~m}$ (3 to $26 \mathrm{ft}$ ) thick. Upper section is alternating blue to green clay, and grayish orange to pink silt and sand beds, thin to medium bedded. Thickest known subsurface section in Mohave Valley is $80 \mathrm{~m}$ (254 ft) (Metzger and Loeltz, 1973); in study area no more than 5 to $10 \mathrm{~m}$ (16 to $32 \mathrm{ft})$ is exposed. Bouse in Mohave Valley is bracketed between 5.5 Ma and 4.1 +/- 0.5 Ma in age (House and others, 2008)

Tsy Younger sedimentary rocks (upper Miocene)-Includes fine-grained deposits of mudstone and shale, siltstone and sandstone, and rarely tuff. In northern Detrital Valley, unit is locally dominated by gypsum and halite. Gypsum beds are white and massive, grading laterally to gypsiferous sandstone, siltstone and mudstone. Halite is not exposed but has been described from drill hole data (Neal and Rauzi, 1996) as at least 220 m (700 ft) thick. Deposited unconformably on older tilted volcanic rocks on east side of valley. As mapped, chiefly composed of units described as Muddy Creek Formation (for example, Laney, 1979) and laterally similar deposits that filled major interior drained basins but are now dissected and exposed because of integration and downcutting by the Colorado River and its tributaries. Unit likely represented by upper $600 \mathrm{~m}$ (1900 ft) of subsurface basin-fill sediment in Hualapai basin, comprising mudstone with lesser gypsum and anhydrite that interfinger laterally away from the playa with sandstone, pebbly sandstone, and conglomerate. Locally faulted but not tilted. About 6 to $9 \mathrm{Ma}$ in age

Tsh Hualapai Limestone (upper Miocene) - Light-gray to pink, algal laminated or marly, resistant limestone, interbedded at base and laterally with red sandstone, pink limey sandstone, gypsiferous sandstone, locally derived coarse sandstone, and rare, poorly sorted reddish-matrix grit and pebble 
conglomerate derived from gneiss. Limestone is commonly vuggy, with vugs resembling cast of plant roots and plant fragments (Faulds and others, 1997), also contains abundant burrows and sole marks in clastic beds (Howard and others, 2003). Overlies Proterozoic rocks in buttress unconformity on west side of Hualapai Wash and overlies or interfingers to east with sandstone and conglomerate in Gregg Basin. Overlain locally by clay

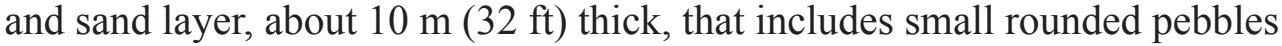
(Faulds and others, 2008). Up to $150 \mathrm{~m}$ (480 ft) thick (Howard and others, 2003). About 6 to $12 \mathrm{Ma}$ in age

Tsmy Intermediate-age sedimentary rocks, younger (upper and middle Miocene) - Mainly red to tan sandstone and conglomerate, but also includes gypsum, limestone, siltstone and mudstone. Typically contains white to silver-gray airfall tuffs that help distinguish it from Tsy. Exposed intermittently from the Black Mountains northeastward to Hualapai Wash. Mostly post-dates volcanism except for isolated younger and intermediate basalts (Tby and Tbm). Widespread exposures in White Hills underlie intermediate age basalts (Tbm) and include coarse conglomerate and debris avalanche deposits containing cobbles, boulders, blocks and crackled sheets of mainly Proterozoic rocks, but including volcanic rocks. Tuffs and tuffaceous sandstone are common. Equivalent to strata mapped widely to the north in the Lake Mead area as the informal red sandstone unit (Bohannon, 1984; about 9 to $13 \mathrm{Ma})$. Unit most likely includes all but upper $600 \mathrm{~m}(1900 \mathrm{ft})$ of sedimentary rocks deposited in Hualapai basin, including $2500 \mathrm{~m}$ (8000 $\mathrm{ft}$ ) of halite, shale and minor evaporite, and laterally equivalent sandstone and conglomerate (Faulds and others, 1997). Deposited in fault-controlled basins and subsequently faulted. Typically slightly or moderately tilted to no more than 30 degrees. On east side of Mohave Mountains in south part of Sacramento Valley, conglomerate underlies mesa-forming basalts dated at $9.2+/-0.3$ and 11.3+/- 0.7 Ma (Suneson and Lucchitta, 1983). Variable thickness of a few tens to a few hundreds of meters. About 9 to $13 \mathrm{Ma}$, but locally may be older

Tsmo Intermediate-age sedimentary rocks, older (middle and lower Miocene)Mostly poorly sorted cobble to boulder conglomerate and large rock avalanche deposits (megabreccias) of mostly Proterozoic rocks, intercalated with volcanic rocks. Known megabreccia deposits crop out in the White Hills and the south and west part of Sacramento Valley. Faulted and folded, most likely preceding or early during deposition of overlying Tsmy. Not exposed between White Hills and the Mohave Mountains, but possibly in subsurface of Detrital and Sacramento Valleys. Deposited in half-graben basins; bedding typically tilted from about 30 to as much as 90 degrees. Variable thickness to as much as 2 to $3 \mathrm{~km}$ ( 1 to $2 \mathrm{mi}$ ) near basin bounding faults (Faulds and others, 2010). About 13 to $16 \mathrm{Ma}$ in age

Tso Older sedimentary rocks (lower Miocene to upper Oligocene) - Composed of conglomerate containing large well-rounded cobbles and small boulders of Proterozoic rocks in arkosic sandstone matrix. Mostly only a few meters thick, but locally includes 100-m- (320-ft-) thick section of fine-grained fluvial rocks (Albin, 1991). Deposited in paleovalleys that are exposed along the Grand Wash Cliffs; overlain by volcanic rocks (Tto, Tvo). Deposits 
originated west of plateau margin and deposited by eastward flowing drainage systems. Older than overlying 20 Ma basalts; inferred to be Oligocene but could be as old as Paleocene

\section{VOLCANIC ROCKS (PLIOCENE, MIOCENE, AND OLIGOCENE)}

Tby Younger basalts (Pliocene and upper Miocene) - Olivine basalt to andesitic basalt flows and associated pyroclastic deposits. Restricted in extent; typically display inverted topography - that is, the flows were originally deposited in channels cut into alluvium but now are higher than surrounding terrane because of removal by erosion of thinner parts and downcutting into less resistant alluvium. Exposed on the flanks of Wilson Ridge, at Sandy Point (unmapped because too small to show at scale of map) in eastern Lake Mead, and as thin flows on the southwest side of Sacramento Valley. Range in age from about 4 to $6 \mathrm{Ma}$

Tbm Intermediate age basalts (upper to middle Miocene)_Tholeiitic olivine basalt flows and breccias and associated pyroclastic deposits. Untilted to slightly tilted and faulted. Includes flows in White Hills (Senator Mountain, Table Mesa, and other slightly tilted flows) and a few small exposures of vent and flow facies in SW Sacramento Valley. About 8 to $12 \mathrm{Ma}$ in age

Tvy Younger rhyolitic to andesitic volcanic rocks (middle Miocene) - Exposed mostly in the western White Hills and west of the community of White Hills in the Black Mountains, where equivalent to Mt Davis Volcanics of Anderson and others (1972). Here, unit comprises pyroxene andesite flows and breccias, minor basalt, and rhyolitic breccias and pyroclastic flows. As much as $600 \mathrm{~m}(1900 \mathrm{ft})$ thick in White Hills. Unit also mapped in southern Sacramento Valley, where comprises rhyolite flows, domes and tuffaceous rocks and local arkosic boulder to cobble conglomerate and sandstone. Clasts in conglomerate are mostly Proterozoic granite gneiss and other metamorphic rocks, with minor basalt. About 13 to $15 \mathrm{Ma}$ in age

Tbo Older basalts (middle Miocene) - Olivine basalt flows and breccias. Exposed only in southern and central Black Mountains on west side of study area. In southern Black Mountains, comprises thick stack of basalt and basaltic andesite flows with phenocrysts of plagioclase, olivine and clinopyroxene. Flows form cap to much of the southern part of the Black Mountains. Locally includes thin tuffaceous sandstone interbeds and rhyolitic ash; entire sequence is as much at $300 \mathrm{~m}(960 \mathrm{ft})$ thick (Dewitt and others, 1986). One K-Ar age of about $15.8 \mathrm{Ma}$ was reported by Gray and others (1990). To north in Grasshopper Junction area basalt flows range in age from about 15.3 to $13.8 \mathrm{Ma}$, and are interlayered in lower part with Tty ( 15 Ma; Varga, 2001). Here, section is about $1 \mathrm{~km}(0.6 \mathrm{mi})$ thick and comprises 1 to $2 \mathrm{~m}$ ( 3 to $6 \mathrm{ft}$ ) thick lava flows, with associated flow breccia, scoriaceous pyroclastic rock and minor sandstone and conglomerate. Locally at base is medium- to coarse-grained sandstone ( 0 to $7 \mathrm{~m} \mathrm{[0}$ to $20 \mathrm{ft}$ ] thick) and matrix-supported conglomerate that fills channels cut into underlying volcanic rocks. Faulted and only slightly tilted relative to moderately to steeply tilted older volcanic rocks. May be down-faulted into Sacramento Valley to east 
Tty Younger rhyolitic ash-flow tuffs (middle Miocene) - Rhyolitic ash-flow tuffs and related airfall tuffs that include the 15.2 Ma tuff of Bridge Spring (Anderson, 1978; Varga and others, 2004), and the 14.97 tuff of Mount Davis (Faulds, 1995). The tuff of Bridge Spring, which outcrops west of the map area in the Eldorado Mountains and on the east side of Detrital Valley, is thought to have been erupted from a caldera in the northern Eldorado Mountains (Gans and others, 1994). Although not thick, the tuffs are persistent. They provide a useful timeline to separate the intermediate-age rhyolitic to andesitic volcanic rocks (Tvm) from the younger rhyolitic to andesitic volcanic rocks (Tvy). Not found south of the central Black Mountains

Tvm Intermediate-age rhyolitic to andesitic volcanic rocks (lower Miocene) Widespread andesitic to basaltic flows and flow breccias, and rhyolitic to dacitic flows, breccias and domes. Exposed extensively in the central and northern Black Mountains and western White Hills. Includes Patsy Mine volcanics of Anderson (1971), the volcanics of the southern White Hills, and volcanics of the Dixie Queen Mine (Faulds and others, 2010) and other ageequivalent volcanic rocks bracketed between the 18.5 Ma Peach Spring Tuff (Nielson and others, 1990) and the 15.2 Ma tuff of Bridge Spring (Varga and others, 2004). Variable thickness, but close to volcanic centers can reach up to 2 to $3 \mathrm{~km}$ ( 1 to $2 \mathrm{mi}$ ) thickness. Mostly faulted and tilted as much as 90 degrees. West of Grasshopper Junction (Varga and others, 2004), andesitic flows and flow breccias are overlain by rhyolitic volcanic sequence that is concentrated in northern part. Includes volcanic center of domes, dikes, and associated rhyolite flows and tuffaceous rocks where thicknesses change from over $300 \mathrm{~m}(960 \mathrm{ft})$ in center to just 1 to $2 \mathrm{~m}$ (3 to $6 \mathrm{ft}$ ) of pyroclastic material to south. Most likely down-faulted into subsurface of northern Sacramento Valley and southern and central Detrital Valley. About 15 to $18 \mathrm{Ma}$ in age

Tto Older rhyolitic ash-flow tuffs (lower Miocene)-Unwelded to welded ash flow tuff unit, deposited in a band from the southern Black Mountains through Kingman to the Grand Wash Cliffs. Includes Peach Spring Tuff (18.5 Ma; Nielson and others, 1990) and associated deposits, and Sitgreaves Tuff of Ransome (1923). Peach Spring Tuff is tan to pink, moderately welded ash flow tuff, with large blue sanidine, quartz and plagioclase phenocrysts. Erupted from Silver Creek caldera on west side of the Black Mountains (Pearthree and others, 2009); associated pyroclastic surge may have reached as much as $100 \mathrm{~km}$ (60 mi) away from the caldera. Thickest deposits are in Black Mountains and eastward in paleovalley at Kingman, along which tuff flowed, covering or flowing around older volcanic rocks (Tvo). Tuff as much as $100 \mathrm{~m}(300 \mathrm{ft})$ thick in deepest parts of paleovalley at Kingman but thins to north and south on margins of paleovalley to about 10 to $30 \mathrm{~m}$ (30 to $100 \mathrm{ft}$ ) thick. East from Kingman, tuff is found in topographically low areas and paleovalleys along Grand Wash Cliffs. It thins gradually from Kingman eastward in the paleovalleys to about $30 \mathrm{~m}(100 \mathrm{ft})$ at the Grand Wash Cliffs. Tuff most likely down-faulted into subsurface of Sacramento Valley

Tvo Older rhyolitic to basaltic volcanic rocks (lower Miocene)-Older mafic to felsic volcanic rocks, including flows, sills, and domes, exposed mostly from Grand Wash Cliffs southwestward, including the Cerbat Mountains, southern Black Mountains, southwest side of Hualapai Mountains, and northern 
Mohave Mountains. Typically underlie older ash flow tuff (Tto); about 18.5 to $20 \mathrm{Ma}$ or older in age. At Kingman, mostly quartz-bearing olivine basalt flows but locally including cinder cones with up to $150 \mathrm{~m}(500 \mathrm{ft})$ relief. Bull Mountain felsic dome, $10 \mathrm{~km}$ south of Kingman, dated at $20.74 \pm 0.56$ Ma (K-Ar; Damon and others, 1996). Buesch and Valentine (1986), describe

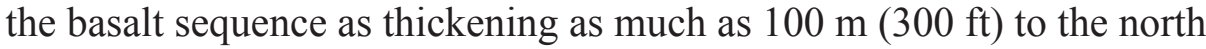
against the Cerbat Mountains and infer the presence of a shield volcano there, now mostly eroded. The volcanic rocks were erupted within and flowed along a paleovalley that is $180 \mathrm{~m}(600 \mathrm{ft})$ or more deep. This paleovalley most likely extended eastward and may be part of the paleovalley at Truxton, Arizona (Young, 2001).

Gently east dipping andesite and basalt flows and breccias overlie Proterozoic rocks on the east flank of the Cerbat Mountains, locally overlain by the older rhyolitic ash-flow tuffs unit (Tto). Crystalline basement on the west flank of the Cerbat Mountains north of Chloride is also overlain by basalt to andesite and felsic ash-flow tuff that dip westward about 20 to 40 degrees (Ferguson and others, 2009). Thomas (1953) mapped the contact between the volcanic rocks and the crystalline basement rocks as the Sacramento Fault; however, Ferguson and others (2009) reinterpreted it as a depositional contact.

At the north end of the Cerbat Mountains, unit includes a thin basal arkosic conglomerate, overlain by a thin sequence of olivine basalt flows. Capped by about $250 \mathrm{~m}$ (800 ft) of matrix-supported, volcaniclastic conglomerate with intercalated andesite lavas and sparse rhyodacite flows. Deposits cut by faults, and may fill an east-trending paleovalley cut into the crystalline rocks of the Hualapai Mountains. Tilted gently to east about 10 to 20 degrees; about 18 to $20 \mathrm{Ma}$ in age (Faulds and others, 2010).

West of Kingman, deposits are exposed in $~ 45-\mathrm{km}-(28-\mathrm{mi}-)$ long north-south band in the Black Mountains. Here, volcanic rocks are underlain locally by as much as $33 \mathrm{~m}$ (100 ft) of fine- to medium-grained arkosic sediments derived from the underlying crystalline rocks, as well as minor amounts of tuff, volcaniclastic sediment, thin algal laminated limestone and thin basalt flows (Gray and others, 1990; Pearthree and others, 2009). Volcanic rocks include latite, dacite, andesite, and rhyolite domes and flows. The rhyolitic rocks are most common in the southeast part of the Black Mountains. Overlain by Peach Spring Tuff and associated deposits (Tto). Section as much as $1 \mathrm{~km}$ (0.6 mi) thick (Pearthree and others, 2009).

\section{INTRUSIVE ROCKS (MIOCENE AND CRETACEOUS)}

Ti Miocene intrusive rocks (middle Miocene) - Intrusive stocks, dikes and plutons in the central and northern Black Mountains. Includes quartz diorite to quartz monzonite of the Wilson Ridge pluton (about 13.5 Ma; Beard and others, 2007) and gabbro and granodiorite of Mt Perkins pluton (16 Ma; Faulds and others, 1999). Mt Perkins pluton forms elongate body parallel to north-northwest faults

Ki Mesozoic intrusive rocks (Late Cretaceous) - Isolated bodies of mediumgrained to slightly porphyritic quartz monzonite, monzogranite and 
granodiorite. Exposed as stocks and small plutons in the Black Mountains, White Hills, Cerbat Mountains, and Mohave Mountains. A small sill-like monzogranite body that intruded into the Muav Limestone in the Grand Wash Cliffs is dated at 65.5 $\pm 3.5 \mathrm{Ma}(\mathrm{K}-\mathrm{Ar}$; reported in Billingsley and others, 2006). In White Hills, quartz monzonite pluton dated at $72.0 \pm 2.1 \mathrm{Ma}$ is associated with gold-bearing quartz veins (Theodore and others, 1987). The Ithaca Peak biotite quartz porphyry stock on the west side of the Cerbat Mountains near Chloride, Arizona, is dated at $71.5 \mathrm{Ma}$ (Wilkinson and others, 1982), and hosts a porphyry copper deposit (Mineral Park Mine)

\section{PALEOZOIC SEDIMENTARY ROCKS}

Pkt Kaibab and Toroweap Formations, undivided (Lower Permian) - Limestone, dolostone, sandstone. Basal part of Toroweap Formation is recessive; basal part is composed of yellow sandstone, dolostone and gypsum of the Seligman Member. Overlain by thick cliff-forming fossiliferous limestone of the Brady Canyon Member. Upper part of Toroweap Formation is Woods Ranch Member, composed of siltstone, mudstone and dolomite. Overlying Kaibab Limestone is represented by the lower $40 \mathrm{~m}(130 \mathrm{ft})$ of the Fossil Mountain Member, a fossiliferous cherty limestone that forms ledges. $140 \mathrm{~m}$ $(450 \mathrm{ft})$ total exposed thickness. Exposed only in northeastern part of study area in Wheeler Ridge

Ph Hermit Formation (Lower Permian) - Distinctive interbedded red sandstone and siltstone. Thin- to medium-bedded, with crossbedding and local ripplelaminations. About $300 \mathrm{~m}(1000 \mathrm{ft})$ thick. Exposed only in northeastern part of study area at Wheeler Ridge

PMs Supai Group, undivided (Lower Permian to Upper Mississippian) - Mostly limestone and dolomite, and subordinate sandy limestone, sandstone, and mudstone. Basal slope-forming part, about $20 \mathrm{~m}(60 \mathrm{ft})$ thick, is alternating limestone and thin red mudstone layers. Overlain by about $220 \mathrm{~m}(700 \mathrm{ft})$ of medium- to thick-bedded limestone and dolomite that grades upward into cliff-forming limestone and interbedded crossbedded limestone. Prominent desert varnish on weathered surfaces makes this part of unit easy to identify from a distance. Overlain by $70-\mathrm{m}-(225-\mathrm{ft}-)$ thick unit of tan to gray ledgeforming dolomite. Unit is capped by about $130 \mathrm{~m}(400 \mathrm{ft})$ of resistant white to red Esplanade Sandstone. Exposed only in northeastern part of study area, in Wheeler Ridge. Part of formation older than Esplanade Formation is equivalent to the Pakoon Limestone and Callville Formations, as described in Beard and others (2007)

Mr Redwall Limestone (Upper and Lower Mississippian) — Thick- to thin-bedded light-gray cherty and fossiliferous micritic limestone. Mostly forms cliff; some recessive cliff zones. Distinctive 30-m- (100-ft-) thick cherty horizon forms distinctive band of alternating dark-brown and light-brown on cliff face. Redwall Limestone is exposed only in northeastern part of study area at Wheeler Ridge, and as small altered outcrop on Wilson Ridge. Thickness, about 180 to $200 \mathrm{~m}(600$ to $640 \mathrm{ft})$

Dtb Temple Butte Formation (Upper and Middle Devonian) - Mostly dolomite, sandstone and limestone. Lower part is purple and gray ripple-laminated 
mudstone, sandstone, dolomite and minor conglomerate that fills channels eroded into underlying Cambrian rocks. Overlain by olive-gray medium- to thick-bedded dolomite and sandy dolomite that form a series of dark-gray ledges, grading from brown to dark-gray dolomite upward to gray dolomite. Unconformity at base represents major stratigraphic break of about $100 \mathrm{~m}$.y. that includes parts of the Late Cambrian, Ordovician and Silurian, and most of Early and Middle Devonian time. Unit exposed only along Grand Wash Cliffs and at far north end of study area in Wheeler Ridge. Thickness, about 120 to $140 \mathrm{~m}$ (400 to $450 \mathrm{ft})$

€m Muav Limestone (Middle Cambrian) - Mainly includes light-gray undivided dolomite, underlain by alternating layers of medium-gray to dark-gray dolomite and thinner layers of orange to brown silty dolomite. Contact with underlying Bright Angel Shale is gradational. Unit exposed only along Grand Wash Cliffs and at far north end of study area in Wheeler Ridge. Thickness, about 360 to $420 \mathrm{~m}$ (1150 to $1650 \mathrm{ft}$ )

Ebt Bright Angel Shale and Tapeats Sandstone, undivided (Middle and Lower

(?) Cambrian) - Middle and Lower Cambrian Bright Angel Shale is dominantly burrow-mottled green micaceous shale and red-brown to brown sandstone. About 90 to $100 \mathrm{~m}$ (300 to $320 \mathrm{ft}$ ) thick. Unit is gradational with underlying Tapeats Sandstone; contact placed where green shales and siltstones become subordinate downward. Lower Cambrian Tapeats Sandstone is crossbedded arkosic sandstone and minor pebbly sandstone. Unconformably overlies irregular surface developed on Proterozoic crystalline rocks; Tapeats Sandstone fills in low areas and locally thins across highlands. Unit exposed only along Grand Wash Cliffs and at far north end of study area in Wheeler Ridge. Thickness, 0 to $60 \mathrm{~m}$ (0 to $200 \mathrm{ft}$ )

\section{PROTEROZOIC CRYSTALLINE ROCKS}

Yg Megacrystic granite (Mesoproterozoic) - Quartz monzonite to granite that typically contain large phenocrysts of potassium feldspar that are up to 8 $\mathrm{cm}$ long and make up from 20 to 70 percent of the rock. The feldspars are commonly zoned or reversely zoned (rapakivi texture) and typically aligned in a magmatic foliation. The granitic matrix is quartz, biotite and plagioclase with abundant magnetite or ilmenite. Albin and Karlstrom (1991) report $\mathrm{U}-\mathrm{Pb}$ zircon ages of 1.39 and $1.37 \mathrm{Ga}$ for the megacrystic granites in the northern Peacock Mountains

Xg Metaintrusive rocks (Paleoproterozoic) - Equigranular to porphyritic granites, granodiorites and other felsic plutonic rocks, mostly deformed into biotite and hornblende-bearing quartzofeldspathic gneisses. Typically foliated

Xgn Metasedimentary and metavolcanic rocks, undivided (Paleoproterozoic) Includes amphibolite, biotite-garnet gneiss, and metasedimentary and metavolcanic rocks, intruded by granite and granodiorite. Also includes migmatite locally. The rocks have been highly deformed by at least two events, imposing strong folding and foliation on the rocks. northweststriking foliation fabric is mostly overprinted by a strong northeast-striking foliation except in the Peacock, Cerbat, and Hualapai Mountains 


\section{References Cited}

Albin, A., 1991, Structural geology of the Gneiss Canyon shear zone in the Peacock Mountains and southern Grand Wash Cliffs, northwestern Arizona: Flagstaff, Northern Arizona University, M.S. thesis, $68 \mathrm{p}$.

Albin, A., and Karlstrom, K.E., 1991, Orthogonal Proterozic fabrics in northwestern ArizonaMultiple orogenic events or progressive deformation during continental assembly, in Karlstrom, K.E., ed., Proterozoc geology and ore deposits of Arizona: Arizona Geological Society Digest, v. 19, p. 67-84.

Anderson, R.E., 1971, Thin-skin distension in Tertiary rocks of southeastern Nevada: Geological Society of America Bulletin, v. 82, p. 43-58.

Anderson, R.E., 1978, Geologic map of the Black Canyon 15-minute quadrangle, Mohave County, Arizona, and Clark County, Nevada: U.S. Geological Survey GQ-1394, scale 1:62,500.

Anderson, R.E., Longwell, C.R., Armstrong, R.L., and Marvin, R.F., 1972, Significance of K-Ar ages of Tertiary rocks from the Lake Mead region, Nevada--Arizona: Geological Society of America Bulletin v. 83, p. 273-288.

Anning, D.L., Flynn, M.E., and Truini, M., 2006, Hydrogeologic investigation of the Detrital, Hualapai, and Sacramento valleys of northwestern Arizona - a project of the Rural Watershed Initiative: U.S. Geological Survey Fact Sheet 2006-3008, 4 p.

Anning D.L., Truini, Margot, Flynn, M.E., Remick, W.H. 2007, Ground-water occurrence and movement, 2006, and water-level changes in the Detrital, Hualapai, and Sacramento Valley Basins, Mohave County, Arizona: U.S. Geological Survey Scientific Investigation Report 2007-5182, 24 p.

Asher-Bolinder, S., Vine, J.D., and Morgan, J.D., 1979, Lithology and lithium content of sediments drilled in a text hole on Red Lake, Hualapai Valley, Mohave County, Arizona: U.S. Geological Survey Open-File Report 79-1439, 20 p.

Beard, L.S., Anderson, R.E., Block, D.L., Bohannon, R.G., Brady, F.J., Castor, S.B., Duebendorfer, D.M., Faulds, J.E., Felger, T.J., Howard, K.A., Kuntz, M.A., and Williams, V.S., 2007, Preliminary geologic map of the Lake Mead 30' X 60' quadrangle, Clark, County, Nevada, and Mohave County, Arizona: U.S. Geological Survey Open-File Report 2007-1010, scale $1: 100,000$.

Billingsley, G.H., Block, D.L., and Dyer, H.C., 2006, Geologic map of the Peach Springs 30' x 60' quadrangle, Mohave and Coconino Counties, northwestern Arizona: U.S. Geological Survey Scientific Investigations Map 2900, pamphlet and map sheet, 16 p., scale 1:100,000.

Blacet, P.M., 1975, Preliminary geologic map of the Garnet Mountain quadrangle, Mohave County, Arizona: U.S. Geological Survey Open-File Report 75-93, scale 1:62,500.

Bohannon, R.G., 1984, Nonmarine sedimentary rocks of Tertiary age in the Lake Mead region, southeastern Nevada and Northwestern Arizona, U.S. Geological Survey Professional Paper 1259, 72 p., 1 plate, scale $1 ; 125,000$

Buesch, D.C., and Valentine, G.A., 1986, Peach Springs tuff and volcanic stratigraphy of the southern Cerbat Mountains, Kingman, Arizona: Geological Society of America Guidebook, no. 5 and no. 6, p. 7-14.

Conway, B.D., Invanich, P.A., 2008, Preliminary estimate of groundwater in storage for the Sacramento Valley groundwater basin, Mohave County, Arizona: Arizona Department of Water Resources, Open File Report No. 10, 28 p.

Conway, C.M., Gonzales, D.A., O'Hara, P.F., and Pitkin, J.A., 1997, Mineral potential report of Hualapai Mountains Land Exchange: Report prepared for U.S. Bureau of Land Management 
and Ironhorse Investors, Inc, by Geologic and Exploration Consulting, Flagstaff, Arizona, 124 p., 2 geologic map plates, scale 1:100,000.

Crafford, A.E.J., 2007, Geologic map of Nevada: U.S. Geological Survey Digital Data Series 249.

Damon, P.E., Shafiqullah, M., Harris, R.C., and Spencer, J.E., 1996, Compilation of unpublished

Arizona K-Ar dates from the University of Arizona Laboratory of Isotope Geochemistry, 1971-

1991: Arizona Geological Survey Open-File Report 6-18, 56 p.

DeWitt, E., Thorson, J.P., and Smith, R.C., 1986, Geology and gold deposits of the Oatman District, northwestern Arizona: U.S. Geological Survey Open-File Report 86-0638, 34 p.

Duebendorfer, E.M., Chamberlain, K.R., Jones, C.S., 2001, Paleoproterozoic tectonic history of the Mojave-Yavapai boundary zone-Perspective from the Cerbat Mountains, northwestern Arizona: Geological Society of America Bulletin, v. 113, p. 575-590.

Duebendorfer, E.M., Chamberlain, K.R., and Fry, B., 2006, Mojave-Yavapai boundary zone, southwestern United States: A rifting model for the formation of an isotopically mixed crustal boundary zone: Geology, v. 34, p. 681-684.

Duebendorfer, E.M., Faulds, J.E., and Fryxell, J.E., 2010, The South Virgin--White Hills detachment fault, southeastern Nevada and northwestern Arizona-Significance, displacement gradient, and corrugation formation, in Umhoefer, P.J., Beard, L.S., and Lamb, M.A., eds., Miocene tectonics of the Lake Mead region, Central Basin and Range: Geological Society of America Special Paper 463, p. 275-287.

Faulds, J.E., 1995, Geologic map of the Mount Davis quadrangle, Nevada and Arizona: Nevada Bureau of Mines and Geology Map 105, 4 p., scale 1:24,000.

Faulds, J.E., Feuerbach, D.L., Miller, C.F., and Smith, E.I., 2001, Cenozoic evolution of the northern Colorado River extensional corridor, southern Nevada and northwest Arizona: Pacific Section of the American Association of Petroleum Geologists Publication GB 78 (also Utah Geological Association Publication 30), p. 239-272.

Faulds, J.E., Howard, K.A., and Duebendorfer, E.M., 2008, Cenozoic evolution of the abrupt Colorado Plateau--Basin and Range boundary, northwest Arizona: A tale of three basins, immense lacustrine-evaporite deposits, and the nascent Colorado River, in Duebendorfer, E.M., and Smith, E.I., eds., Field guide to plutons, volcanoes, faults, reefs, dinosaurs, and possible glaciation in selected areas of Arizona, California, and Nevada: Geological Society of America Field Guide 11, p. 119-151.

Faulds, J.E., Price, L.M., Snee, L.W., and Gans, P.B., 2010, A chronicle of Miocene extension near the Colorado Plateau-Basin and Range boundary, southern White Hills, northwestern Arizona: Palegeographic and tectonic implications, in Umhoefer, P.J., Beard, L.S., and Lamb, M.A., Miocene tectonics of the Lake Mead region: Geological Society of America Special Paper, 463, p. 87-120.

Faulds, J.E., Schreiber, B.C., Reynolds, S.J., Gonzalez, L., and Okaya, D., 1997, Origin and paleogeography of an immense, nonmarine Miocene salt deposit in the Basin and Range (western USA): Journal of Geology, v. 105, p. 19-36.

Faulds, J.E., Smith, E.I., and Gans, P.B., 1999, Spatial and temporal patterns of magmatism and extension in the northern Colorado River extensional corridor, Nevada and Arizona-A preliminary report: Nevada Petroleum Society Guidebook, p. 171-183.

Federal Energy Regulatory Commission, 1982, Red Lake salt cavern gas storage project_final environmental impact statement: Patay Storage Company, Docket no. CP80-581, 258 p.

Felger, T.J., and Beard, L.S., 2010, Geologic map of Lake Mead and the surrounding regions, southern Nevada, southwestern Utah, and northwestern Arizona, in Umhoefer, P.J., Beard, L.S., 
and Lamb, M.A., Miocene tectonics of the Lake Mead region: Geological Society of America Special Paper, 463, p. 29-31, scale 1:250,000.

Ferguson, C.A., Johnson, B.J., Pearthree, P.A., and Spencer, J.E., 2009, Geologic map of the Grasshopper Junction 7.5-minute quadrangle, Mohave County, Arizona: Arizona Geological Survey Digital Geologic Map DGM-70, two plates, scale 1:24,000.

Gans, P.B., Landau, B., and Darvall, P, 1994, Ashes, ashes, all fall down-Caldera-forming eruptions and extensional collapse of the Eldorado Mountains, southern Nevada: Geological Society of America Abstracts with Programs v. 26, p. 53.

Gillespie, J.B. and Bentley, C.B., 1971, Geohydrology of Hualapai and Sacramento valleys, Mohave County, Arizona: U.S. Geological Survey Water Supply Paper 1899-H, p H1-H37, scale $1: 125,000$.

Geosoft, Inc., 2010. Oasis montaj, GM-SYS 3D software.

Goetz, A.F.H., Billingsley, F.C., Gillespie, A.R., Abrams, M.J., Squires, R.L., Shoemaker, E.M., Lucchitta, I., and Elston, D.P., 1975, Application of ERTS images and image processing to regional geologic problems and geologic mapping in northern Arizona: Jet Propulsion Laboratory Technical Report 32-1597, 188 p.

Goff, F.E., Eddy, A.C., and Arney, B.H., 1983, Reconnaissance geologic strip map from Kingman to south of Bill Williams Mountain, Arizona: Los Alamos, New Mexico, Los Alamos National Laboratory, LA-9292-Map, scale 1:48,000.

Gray, Floyd, Jachens, R.C. Miller, R.J., Turner, R.L., Knepper, D.H., Jr., Pitkin, J.A., Keith, W.J., Mariano, John, Jones, S.L., and Korzeb, S.L., 1990, Mineral resources of the Warm Springs Wilderness study area, Mohave County, Arizona: U.S. Geological Survey Bulletin 1737-F, 24 p., 1 plate, scale 1:62,500.

Hildenbrand, T.G., Briesacher, A., Flanagan, G., Hinze, W.J., Hittelman, A.M., Keller, G.R., Kucks, R.P. Pluoff, D., Roest, W., Seeley, J., Smith, D.A., Webring, M., 2002, Rationale and operational plan to upgrade the U.S. Gravity Database: U.S. Geological Survey Open-File Report 02-463, $14 \mathrm{p}$.

House, P.K., Pearthree, P.A., Howard, K.A., Bell, J.W., Perkins, M.E., Faulds, J.E., and Brock, A.L., 2005, Birth of the lower Colorado River-stratigraphic and geomorphic evidence for its inception near the conjunction of Nevada, Arizona, and California, in Pederson, J., and Dehler, C.M., eds., Interior Western United States: Geological Society of America Field Guide 6, p. 357-387.

House, P.K., Pearthree, P.A., and Perkins, M.E., 2008, Stratigraphic evidence for the role of lake spillover in the inception of the lower Colorado River in southern Nevada and western Arizona: Geological Society of America Special Paper 439, p 335-353.

Howard, K.A., and John, B.E., 1987, Crustal extension along a rooted system of imbricate lowangle faults - Colorado River extensional corridor, California and Arizona, in Coward, M.P., Dewey, J.F., and Hancock, P.L., eds., Continental extensional tectonics: Geological Society of London Special Publication 28, p. 299-311.

Howard, K.A., John, B.E., and Nielson, J.E., 1997, Preliminary geologic map of the eastern and northern parts of the Topock 7.5-minute quadrangle, Arizona and California: U.S. Geological Survey Open-File Report 95-534, scale 1:24,000.

Howard, K.A., Hook S.J., Phelps, G.A., and Block, D.L., 2003, Geologic map of the Hiller Mountains quadrangle, Clark County, Nevada, and Mohave County, Arizona: Nevada Bureau of Mines and Geology Map 137, pamphlet 8 p., scale 1:24,000.

Howard, K.A., Nielson, J.E. ,Wilshire, H.G., Nakata, J.K., Goodge, J.W., Reneau, S.L., John, B.E., 
and Hansen, V.L, 1999, Geologic map of the Mojave Mountains area, Mojave County, western Arizona, U.S. Geological Survey Miscellaneous Investigations Series I-2308, scale 1:100,000. Ivanich, P.A., and Conway, B.D., 2009, Preliminary estimate of groundwater in storage for the Hualapai Valley Groundwater basin, Mohave County, Arizona: Arizona Department of Water Resources Open-File Report, 31 p.

Laney, R.L., 1979, Geohydrologic reconnaissance of Lake Mead National Recreation Area-Hoover Dam to Temple Bar, Arizona: U.S. Geological Survey Open-File Report 79-689, map scale 1:62500.

Langenheim, V.E., Beard, L.S., and Faulds, J.E., 2010, Implications of geophysical analysis on basin geometry and fault offsets in the northern Colorado River extensional corridor and adjoining Lake Mead region, Nevada and Arizona, in Umhoefer, P.J., Beard, L.S., and Lamb, M.A., eds., Miocene tectonics of the Lake Mead region, Central Basin and Range: Geological Society of America Special Paper, p. 39-61.

Lister, L.A., and Secrest, C.D., 1985, Giant desiccation cracks and differential surface subsidence, Red Lake playa, Mohave County, Arizona: Bulletin of the Association of Engineering Geologists, v. 12, p. 299-314.

Lucchitta, I., and Suneson, N.H., 1994, Geologic map of the Castaneda Hills quadrangle, Mohave County, Arizona: U.S. Geological Survey GQ-1720, scale 1:24,000.

Ludington, S., Moring, B.C., Miller, R.J., Stone, P.A., Bookstrom, A.A., Bedford, D.R., Evans, J.G., Haxel, F.A., Nutt, C.J., Flyn, K.S., and Hopkins, M.J., 2007, Preliminary integrated geologic map databases for the United States: U.S. Geological Survey Open-File Report 20051305, version 1.1.

Mason, D.A., Ivanich, P.A., Conway, B.D., Kurtz, J.A., and Will, M.T., 2007, Preliminary estimate of water in storage for the Detrital Valley ground-water basin, Mohave County, Arizona: Arizona Department of Water Resources Open-File Report Number 9, 31 p.

Metzger, D.G., and Loeltz, O.J., 1973, Geohydrology of the Needles area, Arizona, California, and Nevada: U.S. Geological Survey Professional Paper 486-J, 54 p.

Mörz, T., 1996, Der Proterozoische Cerbat Mountain complex in NW Arizona (USA), als möglicher Teil der Mojave/Yavapai-Sutur: Eine petrographische und strukturelle Aufnahme: Tübingen, Germany, Eberhard-Karls-Universität Tübingen, M.S. thesis, 198 p., scale 1:12,000.

Murphy, R.T., Faulds, J.E., and Hillemeyer, F.L., 2004, Preliminary geologic map of the north half of the Union Pass quadrangle, Mohave County, Arizona: Nevada Bureau of Mines and Geology, scale 1:24,000.

Neal, J.T., Langer, A.M., and Kerr, P.F., 1968, Giant desiccation polygons of Great Basin playas: Geological Society of America Bulletin, v. 79, pp. 69-90.

Neal, J.T., and Motts, W.S., Recent geomorphic changes in playas of western United States: Journal of Geology 75 (1967) (5), p. 511-525.

Neal, J.T., and Rauzi, S.L., 1996, Storage opportunities in Arizona bedded evaporites: Arizona Geological Survey Open-file Report 96-27, 16 p.

Nielson, J.E., Lux, D.R., Dalrymple, G.B., and Glazner, A.F., 1990, Age of the Peach Springs Tuff, southeastern California and western Arizona: Journal of Geophysical Research, v. 95, p. 571580.

PACES, 2008, Geonet gravity and magnetic dataset repository: Pan-American Center for Earth and Environmental Studies (PACES), http://irpsrvgis00.utep.edu/repositorywebsite/.

Pearce, J.L., 2010, Syntectonic deposition and paleohydrology of the spring-fed Hualapai Limestone and implications for 5-6 Ma integration of the Colorado River system through Grand 
Canyon - evidence from sedimentology, chemostratigraphy, and detrital zircon analysis: Albuquerque, New Mexico, University of New Mexico, M.S. thesis, 205 p.

Pearthree, P.A, Ferguson, C.A., Johnson, B.J., and Guyn, J., 2009, Geologic map and report for the proposed State Route 95 realignment corridor, Mohave County, Arizona, Version 1.0: Arizona Geological Survey Digital Geologic Map DGM-65, 44 p, scale 1:24000.

Prante, M.R., 2009, Paleoproterozoic deformation and metamorphism in the Peacock Mountains, northwest Arizona-Implications for Paleoproterozoic tectonics: Northern Arizona University, Flagstaff, M.S. thesis, 101 p., map scale unknown.

Ransome, F.L., 1923, Geology of the Oatman gold district, Arizona, a preliminary report: U.S. Geological Survey Bulletin 743, 58 p.

Richard, S.M., Reynolds, S.J., Spencer, J.E., and Pearthree, P.A., compilers, 2000, Geologic map of Arizona: Arizona Geological Survey Map M-35, scale 1:1,000,000.

Saltus, R.W., and Jachens, R.C., 1995, Gravity and basin-depth maps of the Basin and Range Province, western United States: U.S. Geological Survey Geophysical Investigations GP-1012, scale 1:2,500,000.

Sante Fe Pacific Railroad Company, 1981, Geologic map of Sante Fe Pacific Railroad Company mineral holdings in northwestern Arizona: Arizona Geological Survey Miscellaneous Maps MM-88A, scale 1:1,100,000.

Simpson, R.W., Jachens, R.C., and Blakely, R.J., 1983, Airyroot-A Fortran program for calculating the gravitational attraction of an airy isostatic root out to 166.7 KM: U.S. Geological Survey Open-File Report 83-883, 66 p.

Siwec, B.R., 2003, Tectonic implications of Paleoproterozoic structure and metamrophism in the northern Hualapai Mountains, Mohave County, Arizona: Flagstaff, Northern Arizona University, MS Thesis, 103 p., scale 1:12,000.

Stang, H., and Kollet, S., 1998, Geologic map of south Cerbat Mountains, Arizona, USA: Institute for Geology and Paleontology, University of Tubingen, Map from MS thesis, scale 1:10,000.

Suneson, N.H., and Lucchitta, I., 1983, Origin of bimodal volcanism, southern Basin and Range province, west-central Arizona: Geological Society of America Bulletin, v. 94, p. 1005-1019.

Theodore, T.G., Blair, W.N., and Thomas, J.T., 1987, Geology and gold mineralization of the Gold basin-Lost basin mining districts, Mohave County, Arizona: U.S. Geological Survey Professional Paper 1361, $167 \mathrm{p}$.

Thomas, B.E., 1953, Geology of the Chloride quadrangle, Arizona: Geological Society of America Bulletin, v. 64, p. 391-420, 1 plate, scale unknown.

Thorson, 1971, Igneous petrology of the Oatman district, Mohave County, Arizona: University of California, Santa Barbara, Ph.D. dissertation,189 p., 2 plates, scale 1:24,000.

Varga, R.J., 2001, Geologic map of the Grasshopper Junction SE quadrangle, Mohave County, Arizona: Arizona Geological Survey, Contributed Map CM-04-B, scale 1:24,000.

Varga, R.J., Faulds, J.E., Snee, L.W., Harlan, S.S., and Bettison-Varga, L, 2004, Miocene extension and extensional folding in an anticlinal segment of the Black Mountains accommodation zone, Colorado River extensional corridor, southwestern United States: Tectonics, v. 23, 19 p.

Weber, M.E., and Smith, E.I., 1987, Structural and geochemical constraints on the reassembly of disrupted mid-Miocene volcanies in the Lake Mead-Eldorado Valley area of southern Nevada: Geology, v. 15, p. 553-556.

Wilkinson, W.H., Vega, L.A., and Titley, S.R., 1982, Geology and ore deposits at Mineral Park, Mohave County, Arizona, in Titley, S.R., ed., Advances in geology of porphyry copper deposits: Tucson, University of Arizona Press, p. 523-541.

Wooden, J.L., and DeWitt, E., 1991, Pb isotopic evidence for a major Early Proterozoic crustal boundary in western Arizona, in Karlstrom, K.E., ed., Proterozoic geology and ore deposits of 
Arizona: Arizona Geological Digest 19, p. 27-50.

Young, R.A., 2001, Geomorphic, structural, and stratigraphic evidence for Laramide Uplift of the southwestern Colorado Plateau margin of NW Arizona: Pacific Section of the American Association of Petroleum Geologists Publication GB 78 (also Utah Geological Association Publication 30), p. 227-237. 


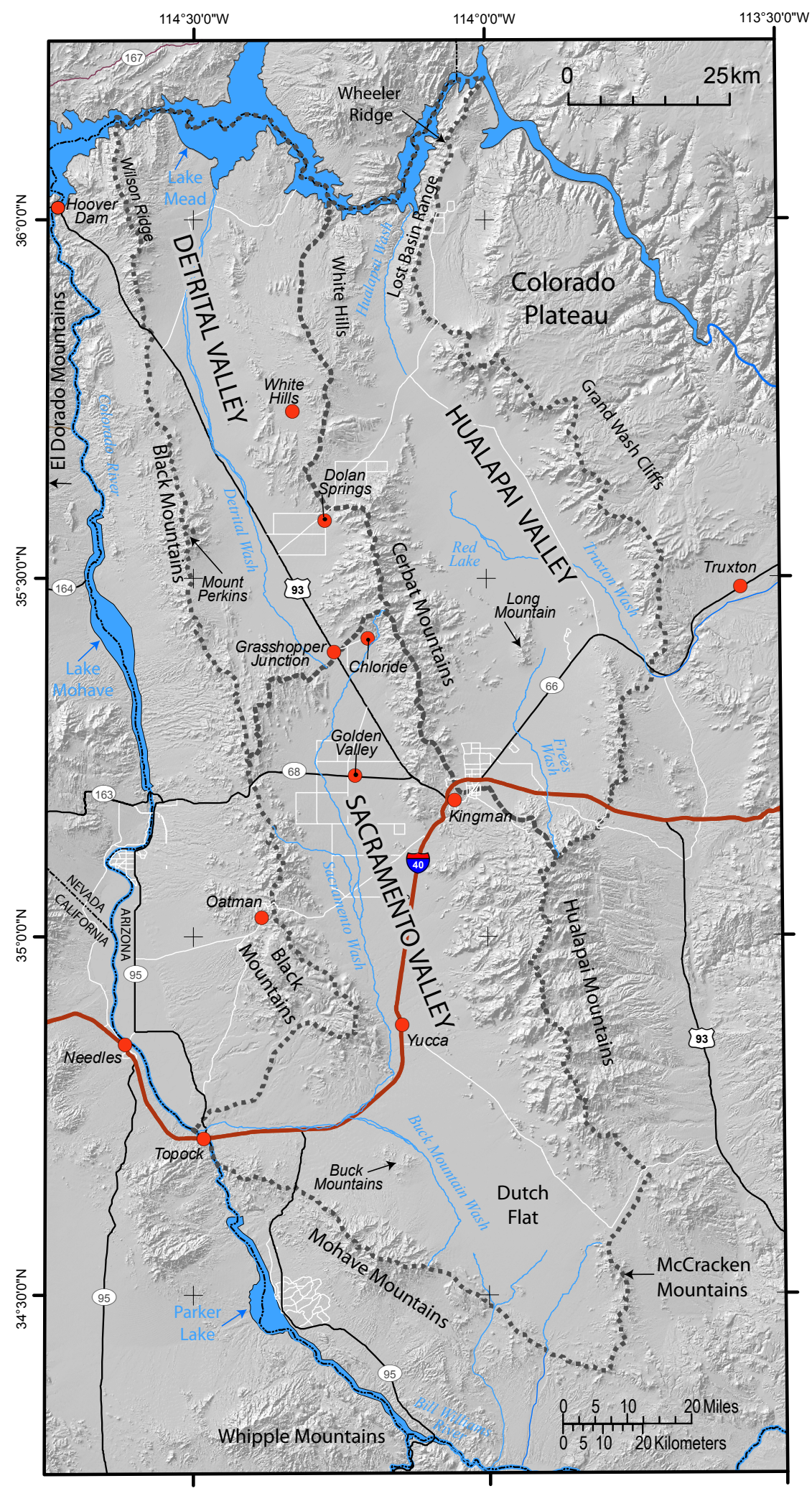

Figure 1. Shaded-relief map showing hydrologic basin boundary of Detrital, Hualapai, and Sacramento valley basins (thick black dashed line), and highways, towns, and other physiographic and cultural features referred to in text. Eldorado Mountains are about $30 \mathrm{~km}$ west of the map area and form the west side of the Colorado River valley and Lake Mohave, from Hoover Dam southward to about latitude $35^{\circ} 30^{\prime} 00^{\prime \prime}$. State lines shown by black dash. 




Figure 2. Depth-to-bedrock gravity model showing subbasins and estimated thickness of basin fill beneath Hualapai, Detrital, and Sacramento Valley basins. 

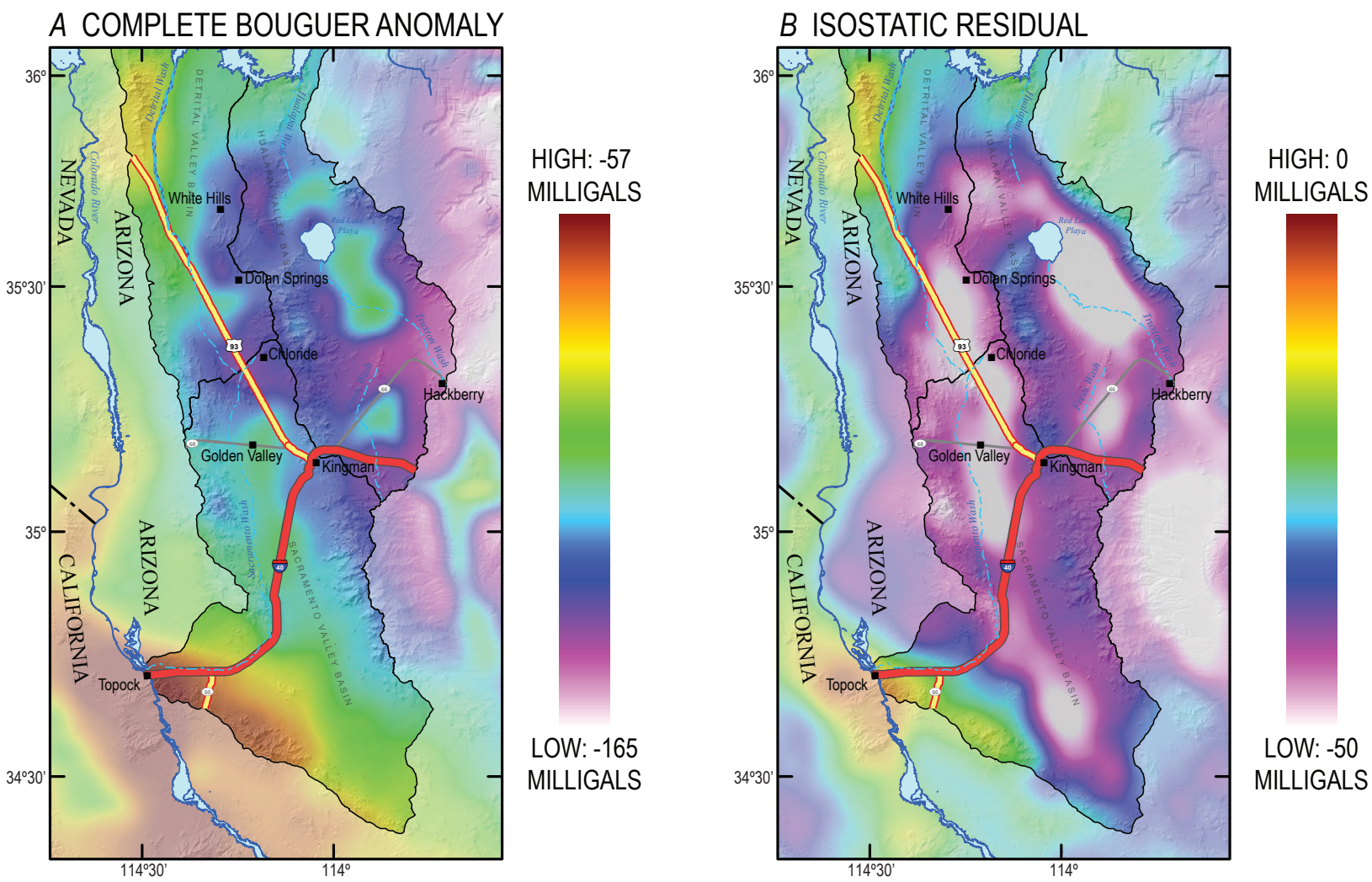

\section{BEDROCK RESIDUAL}
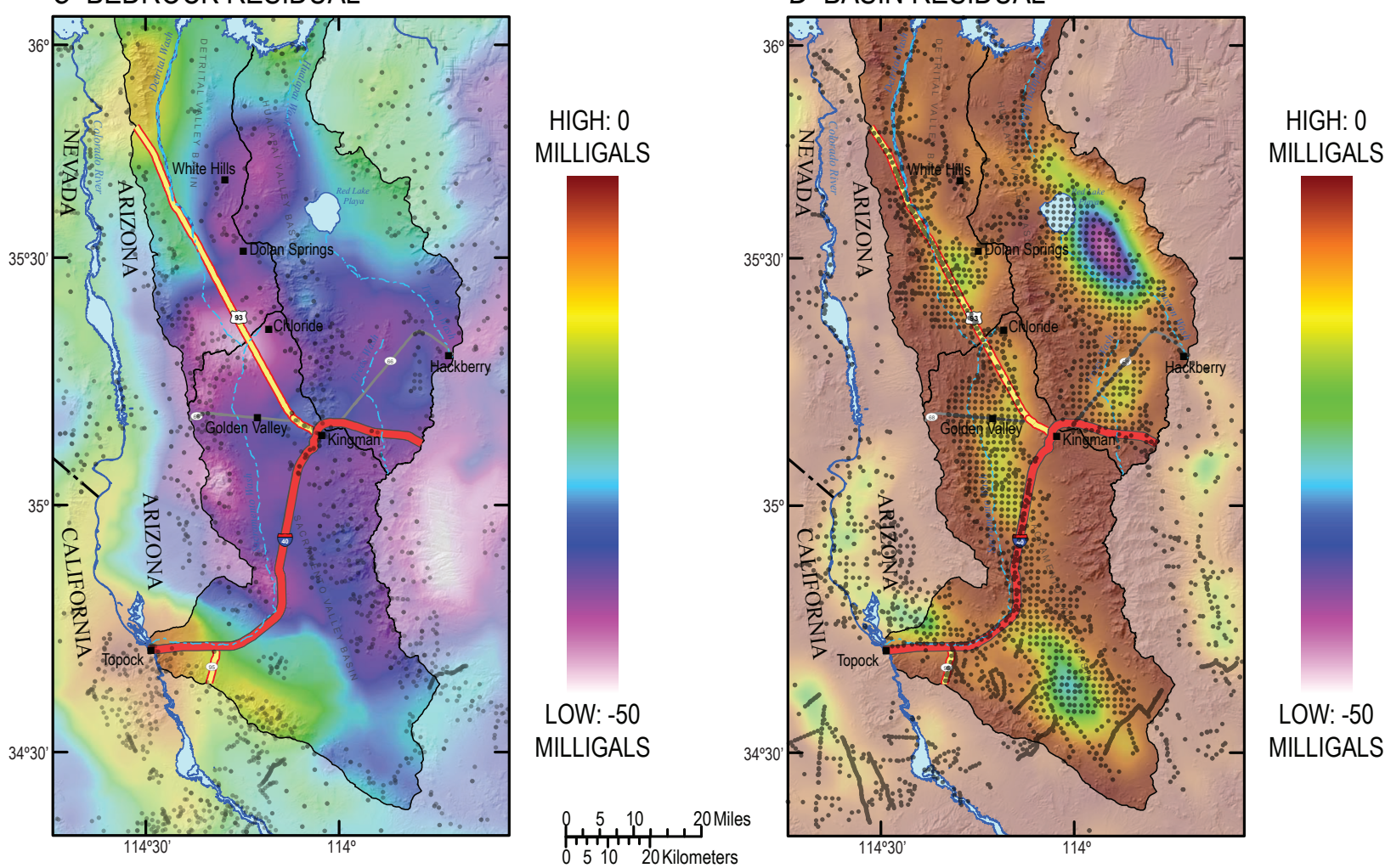

Figure 3. Gravity data used to create depth-to-bedrock model, overlain by outline of map area. A, Complete Bouger anomaly; $\boldsymbol{B}$, Isostatic residual anomaly; $\boldsymbol{C}$, Bedrock residual anomaly; and $\boldsymbol{D}$, Basin residual anomaly. Open-circles on $\mathbf{C}$ and $\mathbf{D}$ indicate position of gravity measurements. All grids are upward continued to $2,550 \mathrm{~m}$ elevation. 
Quaternary and late Tertiary surficial deposits

Tertiary sedimentary rocks

Tertiary volcanic rocks

Tertiary intrusive rocks

Early Tertiary to Late Cretaceous intrusive rocks

Mesozoic sedimentary rocks

Permian and Pennsylvanian sedimentary rocks

Mississippian and Devonian sedimentary rocks

Cambrian sedimentary rocks

Mesoproterozoic and Paleoproterozoic crystalline rocks

State Boundary
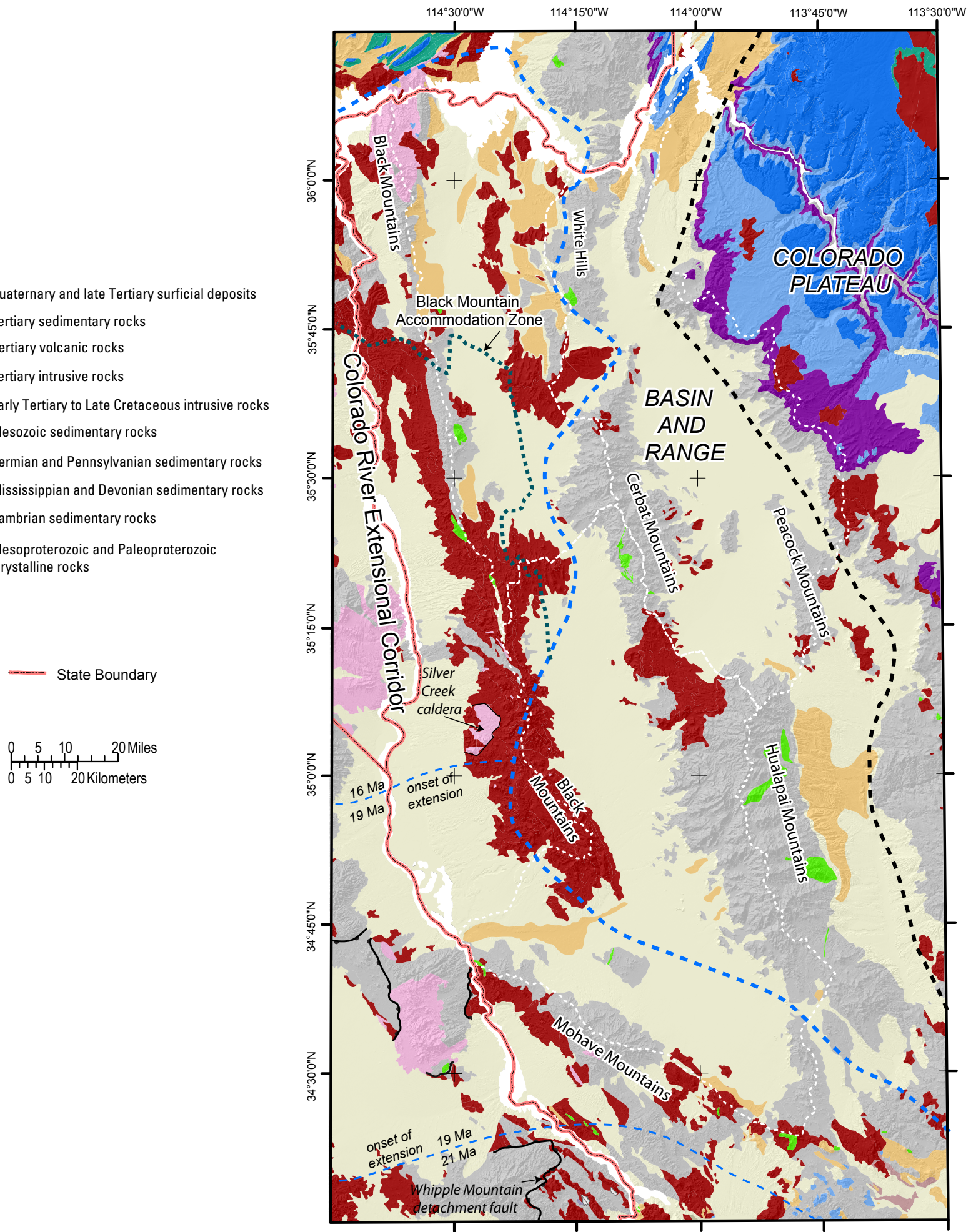

Figure 4. Regional geologic map showing major geologic features referred to in text. Heavy dashed black line is boundary between Colorado Plateau and Basin and Range. Heavy blue dashed line is eastern edge of extensive volcanism in Colorado River extensional corridor; thin blue dashed line shows approximate onset time of extension within extensional corridor. Dark-green dashed line shows axis of Black Mountain accommodation zone. White dashed line marks drainage divides between valleys as shown in figure 1. Geology modified from state geologic maps (Crafford, 2007; Ludington and others, 2007; Richard and others, 2000), overlain on shaded-relief base map created from 30-m DEM. 
$A$

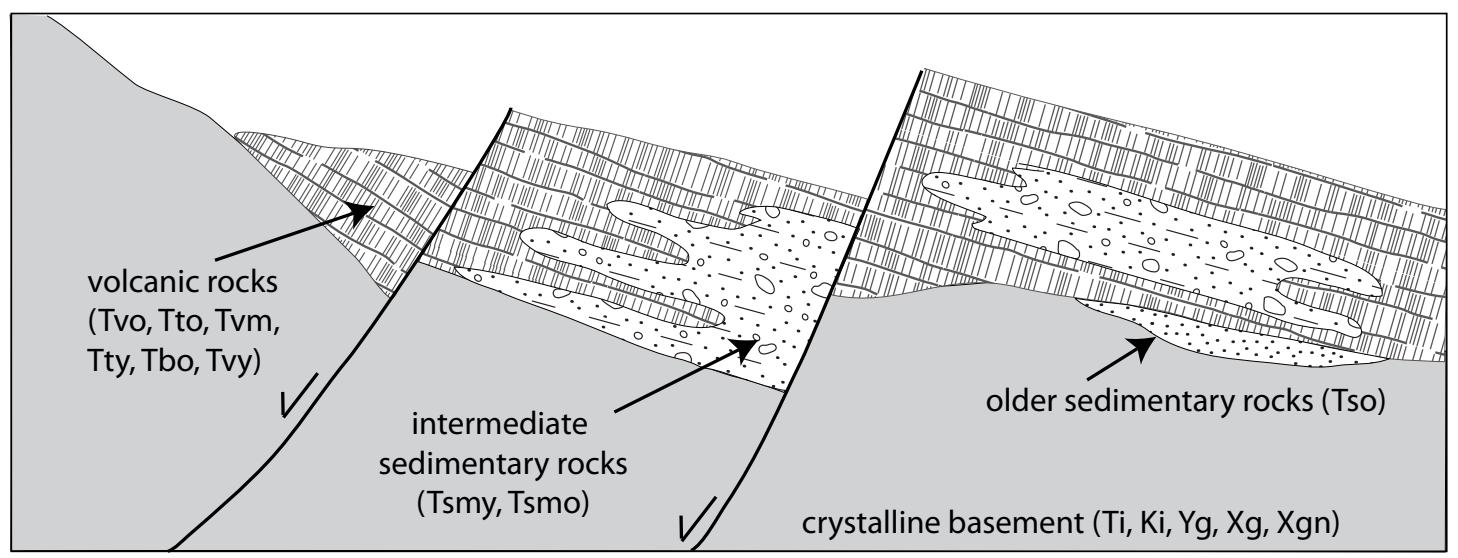

B

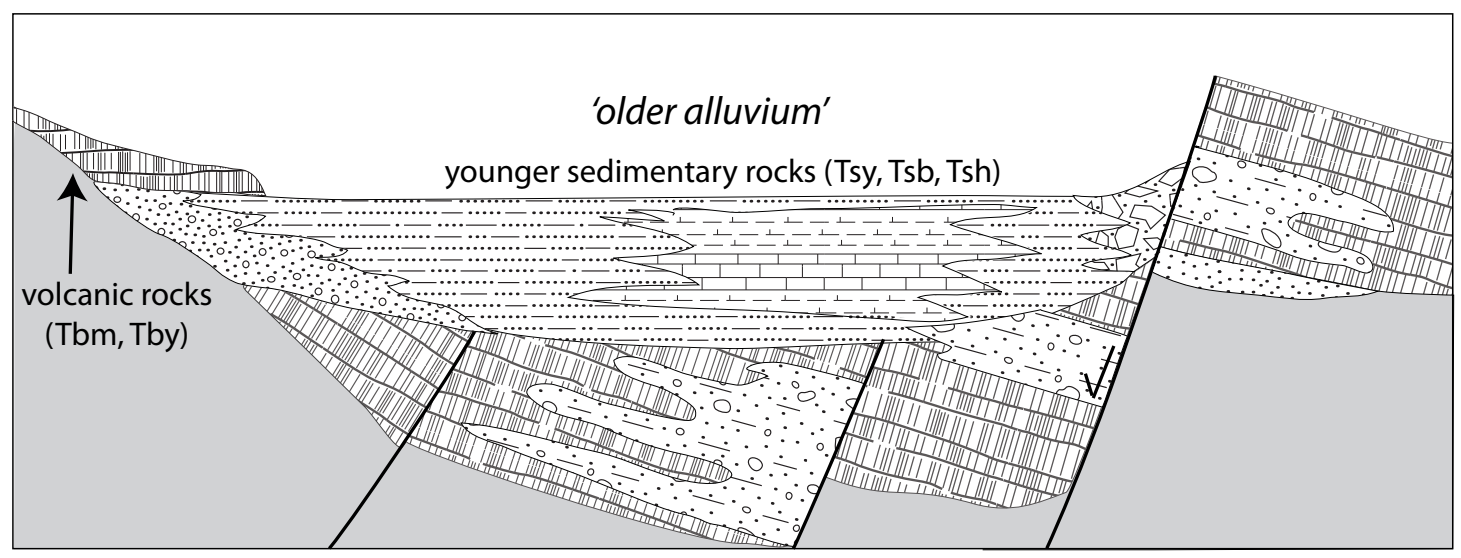

C

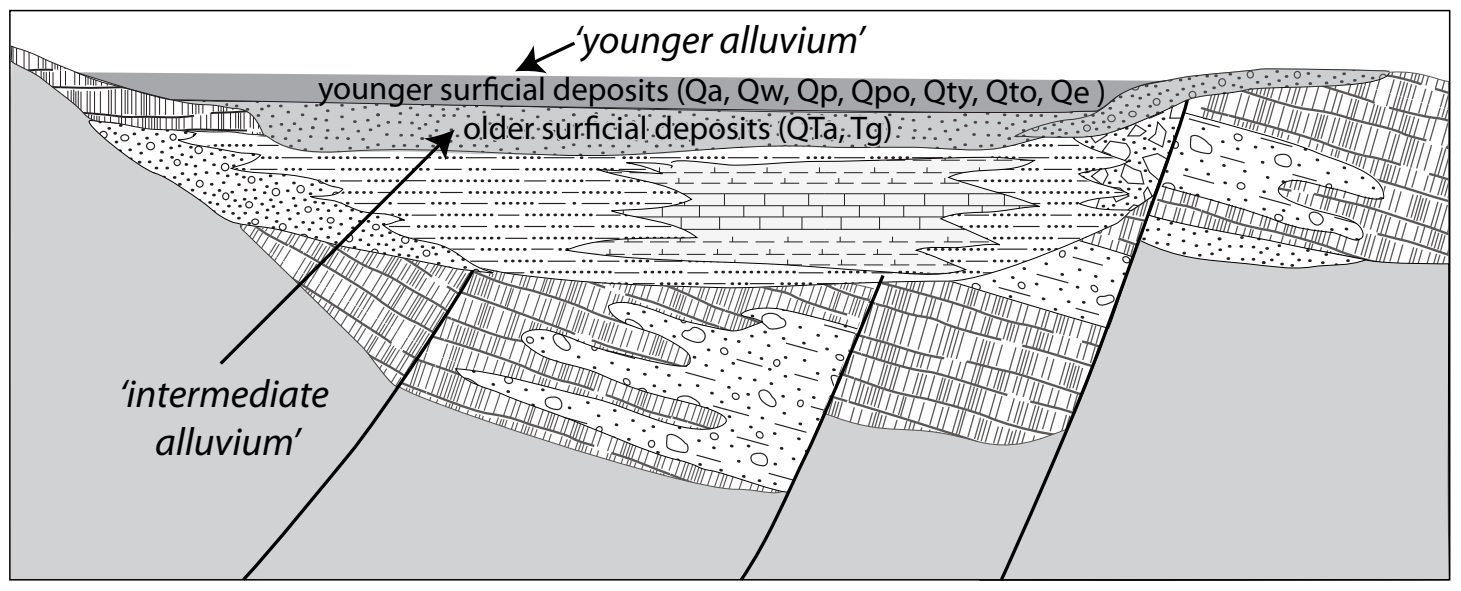

Figure 5. Schematic sequential cross sections showing extensional basin evolution and stratigraphic relations between older, intermediate, and younger sedimentary rocks. Sections also show correlation of sedimentary rocks to "older, intermediate and younger alluvium" of Gillespie and Bentley (1971) and Anning and others (2007). A, Extension from about 16 to $13 \mathrm{Ma}$ forms half-graben basins that include coarse alluvial conglomerates and breccias sheets of intermediate-age sedimentary rocks (Tsmy, Tsmo) that are shed from active faults are and interlayered with volcanic flows. Note pre-extensional older sedimentary rocks (Tso) filling paleovalley beneath volcanic rocks. B. Continued faulting (13- $8 \mathrm{Ma}$ ) forms younger subbasins filled by mostly fine-grained younger sedimentary rocks (Tsy, Tsb, Tsh). These rocks correspond to the "older alluvium". C, Late Pliocene to Quaternary surficial deposits blanket surface of subbasins within valley basin. The older surficial deposits (QTa, $\mathbf{T g}$ ) are typically exposed only at the edges of the valley basins and correspond to the "intermediate alluvium". Younger surficial deposits are equivalent to "younger alluvium" and include Qa, Qw, Qp, Qpo, Qty, Qto and Qe. 


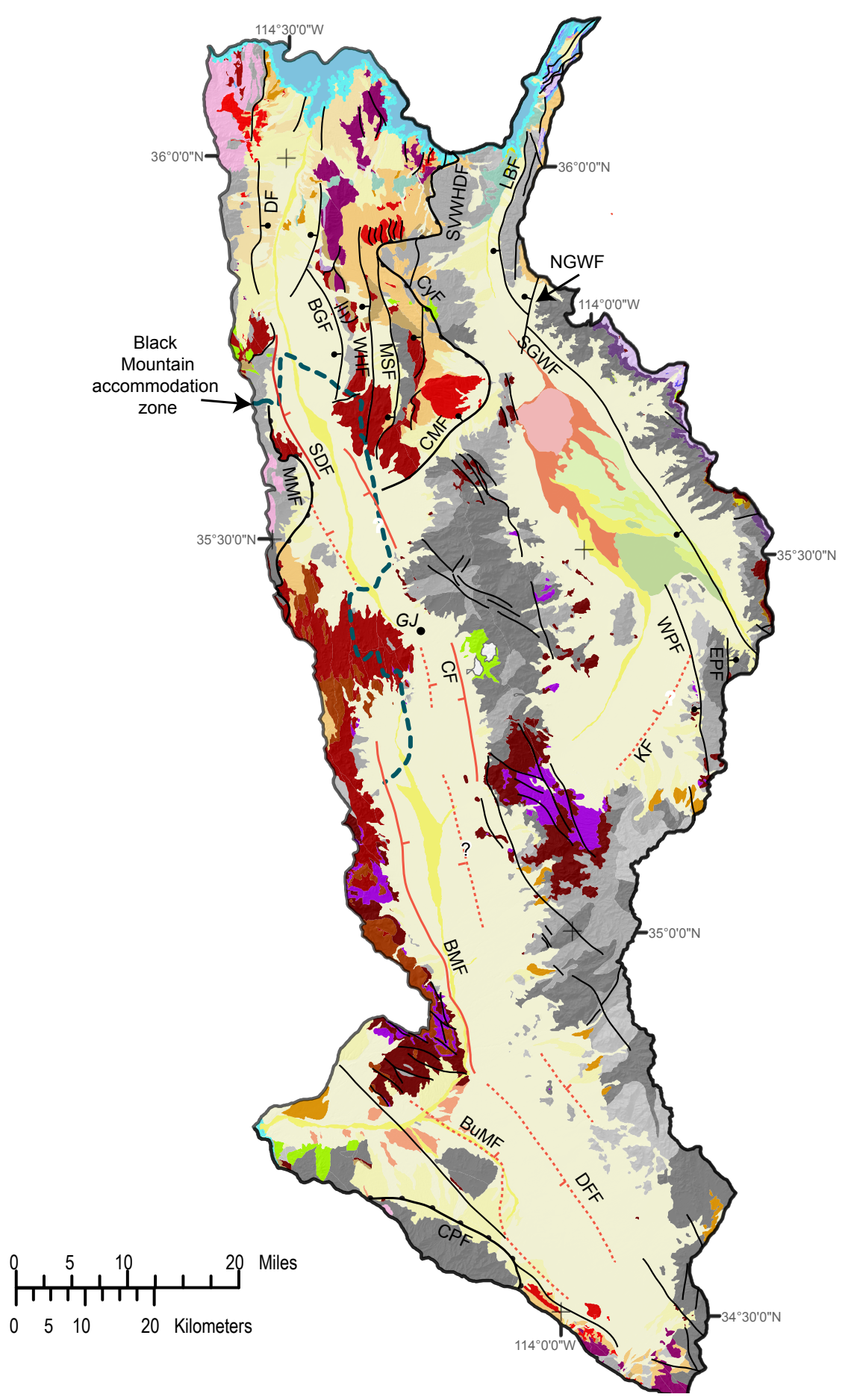

Figure 6. Geologic map of study area showing major faults and other structural features. Mapped faults are shown in black; black lines with semi-circle ornamentation are low-angle detachment faults. Faults inferred from depth-to-bedrock gravity model and GEOTEM data shown in red. Dashed red lines denote higher degree of uncertainty (see text and table 1 for additional discussion.) Thick dark-green dashed line is Black Mountain accommodation zone. Fault abbreviations as follows: BGF, Blind Goddess Fault; BMF, Black Mountain Fault; BuMF, Buck Mountains Fault; CF, Chloride Fault; CMF, Cerbat Mountain Fault; CPF, Crossman Peak Fault; CyF, Cyclopic Mine Fault; DDF, Dutch Flat Fault; DF, Detrital Fault; EPF, east Peacock Fault; KF, Kingman Fault; LBF, Lost Basin Range Fault; MMF, Mockingbird Mine Fault; MSF, Mountain Spring Fault; NGWF, Northern Grand Wash Fault; SDF, south Detrital Fault; SGWF, southern Grand Wash Fault; SVWHDF, South Virgin White Hills Detachment Fault; WHF, White Hills Fault; WPF, west Peacock Fault; GJ, location of Grasshopper Junction. 


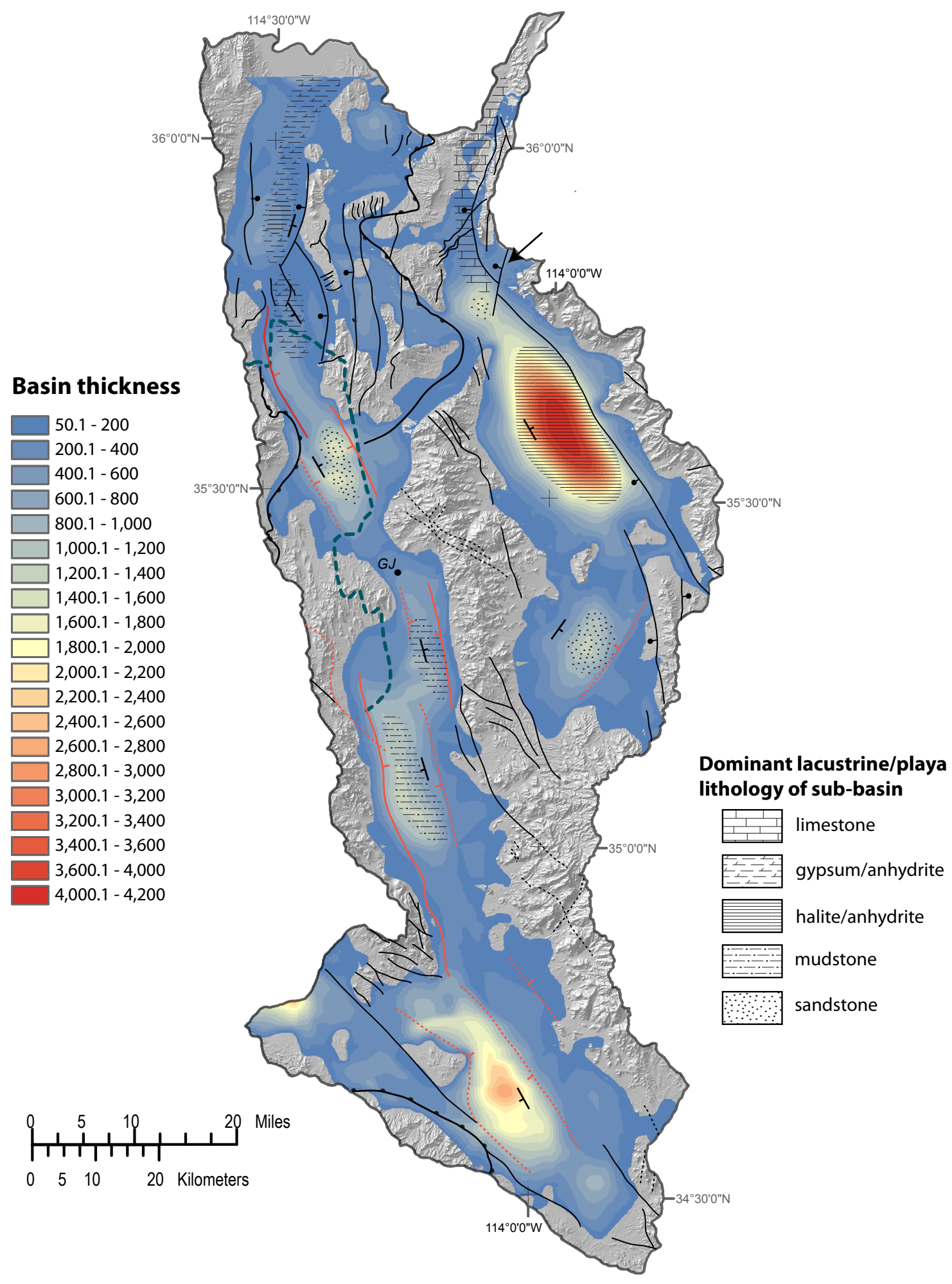

Figure 7. Depth-to-bedrock gravity model shows subbasins in relation to faults as shown in figure 6 . See figure 2 for subbasin names. Black lines are mapped faults, bar and ball on downthrown side; barbed faults are detachment faults with barbs facing upper plate. Red lines are faults inferred from geophysics; dashed red line denotes higher degree of uncertainty. Red barbs on inferred geophysical fault point toward down-dropped block. Thick dark-green dashed line is Black Mountain accommodation zone. GJ, location of Grasshopper Junction. Patterns show distinctive lacustrine facies of northern subbasins; the lithology of the Dutch Flat subbasin is unknown. 
Table 1. Geologic characteristics of sub-basins for Detrital, Hualapai, and Sacramento valley basins; see figures 1 and 2 for subbasin locations; see figure 7 for fault locations and lithology of subbasins

\begin{tabular}{|c|c|c|c|c|}
\hline Sub-basin & $\begin{array}{l}\text { Modeled } \\
\text { Depth }\end{array}$ & Geometry & Faults & $\begin{array}{l}\text { Lithology of lacustrine/playa } \\
\text { deposits }\end{array}$ \\
\hline \multicolumn{5}{|l|}{ Detrital Valley } \\
\hline northern Detrital subbasin & $600 \mathrm{~m}$ & graben & Detrital Fault, unnamed fault on east side & halite, anhydrite, gypsum, clay \\
\hline central Detrital subbasin & $700 \mathrm{~m}$ & $\begin{array}{l}\text { west-tilted half- } \\
\text { graben }\end{array}$ & $\begin{array}{l}\text { south Detrital Fault or Mockingbird Mine } \\
\text { Fault on west side, Blind Goddess Fault } \\
\text { on east side }\end{array}$ & anhydrite, gypsum, clay \\
\hline southern Detrital subbasin & $1500 \mathrm{~m}$ & $\begin{array}{l}\text { east-tilted half- } \\
\text { graben, or full } \\
\text { graben }\end{array}$ & $\begin{array}{l}\text { unnamed fault on east side, possible } \\
\text { fault on west side }\end{array}$ & $\begin{array}{l}\text { clay and other fine-grained clastic } \\
\text { deposits }\end{array}$ \\
\hline \multicolumn{5}{|l|}{ Hualapai Valley } \\
\hline Hualapai subbasin & $4300 \mathrm{~m}$ & $\begin{array}{l}\text { east-tilted half- } \\
\text { graben }\end{array}$ & southern Grand Wash Fault & halite, anhydrite, gypsum, clay \\
\hline Kingman subbasin & $1200 \mathrm{~m}$ & $\begin{array}{l}\text { faulted } \\
\text { paleovalley, or } \\
\text { possible southeast- } \\
\text { tilted half-graben }\end{array}$ & $\begin{array}{l}\text { Kingman Fault on southeast side, west } \\
\text { Peacock Fault on east side }\end{array}$ & $\begin{array}{l}\text { clay and other fine-grained clastic } \\
\text { deposits }\end{array}$ \\
\hline southern Gregg subbasin & $1400 \mathrm{~m}$ & graben? & $\begin{array}{l}\text { Lost Basin and southern Grand Wash } \\
\text { faults on east side, possible fault on west }\end{array}$ & $\begin{array}{l}\text { limestone interfingering southward } \\
\text { with clay and other fine-grained } \\
\text { clastic deposits }\end{array}$ \\
\hline \multicolumn{5}{|l|}{ Sacramento Valley } \\
\hline Chloride subbasin & $900 \mathrm{~m}$ & $\begin{array}{l}\text { east-tilted half- } \\
\text { graben, or full } \\
\text { graben }\end{array}$ & $\begin{array}{l}\text { Chloride Fault on east side, possible fault } \\
\text { on west side }\end{array}$ & $\begin{array}{l}\text { clay and other fine-grained clastic } \\
\text { deposits }\end{array}$ \\
\hline Golden Valley subbasin & $1300 \mathrm{~m}$ & $\begin{array}{l}\text { west-tilted half- } \\
\text { graben, or full } \\
\text { graben }\end{array}$ & $\begin{array}{l}\text { Black Mountain Fault on west side, } \\
\text { possible fault on east side }\end{array}$ & $\begin{array}{l}\text { clay and other fine-grained clastic } \\
\text { deposits }\end{array}$ \\
\hline Dutch Flat subbasin & $2600 \mathrm{~m}$ & $\begin{array}{l}\text { west tilted half- } \\
\text { graben? }\end{array}$ & $\begin{array}{l}\text { Buck Mountain and Crossman Peak faults } \\
\text { on west side, possible fault on east side }\end{array}$ & unknown \\
\hline
\end{tabular}

